\title{
Evaluating the role of sulfide-weathering in the formation of sulfates or carbonates on Mars
}

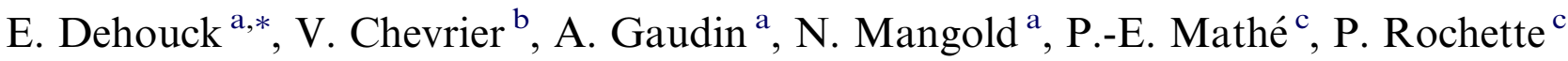 \\ ${ }^{a}$ Laboratoire de Planétologie et Géodynamique de Nantes, CNRS/Université de Nantes, UMR 6112, 44322 Nantes, France \\ ${ }^{\mathrm{b}}$ Arkansas Center for Space and Planetary Sciences, MUSE 202, University of Arkansas, Fayetteville, AR 72701, USA \\ ${ }^{\mathrm{c}}$ Centre Européen de Recherche et d'Enseignement en Géosciences de l'Environnement, Europôle de l'Arbois, 13545 Aix-en-Provence, France
}

Received 28 June 2011; accepted in revised form 27 April 2012; available online 8 May 2012

\begin{abstract}
Orbital and landed missions to Mars have revealed complex sulfate- and Fe-oxide-bearing mineralogical assemblages, which have been interpreted as the result of a late planet-wide acidic period due to large $\mathrm{SO}_{2}$ emissions. However, this global scenario does not explain the recent discovery of Hesperian and Noachian-aged carbonates in several regions, because they should have been dissolved by the acidic conditions, nor the restriction of sulfate occurrences in preferential regions. Here we present the results of a 4-year-long experimental study designed to test the impact of $\mathrm{Fe}$-sulfides (pyrrhotite $\mathrm{Fe}_{0.9} \mathrm{~S}$ ) on the weathering of basaltic silicates (olivine, clino- and orthopyroxene) under an early-Martian-like, $\mathrm{CO}_{2}$-rich atmosphere. Our weathered silicate/sulfide mixtures showed complex parageneses containing elemental sulfur, hydrated sulfates (gypsum, hexahydrite, jarosite) and Fe-(oxy)hydroxides. Olivine-only samples produced nesquehonite, an Mg-carbonate precursor of hydromagnesite and magnesite. These secondary phases are similar to those observed in the Martian sulfate- and carbonatebearing deposits. Therefore, we propose a geochemical model in which, on the one hand, Martian sulfates mainly formed from weathering of sulfide-enriched basalts producing locally acidic environments and, on the other hand, carbonates were preserved and could even have formed in regions initially devoid of sulfides, thereby resolving the apparent paradox arising from the possible coeval formation of the two types of minerals. These results raise doubts on the need for a global acidic event to produce the sulfate-bearing assemblages, suggest that regional sequestration of sulfate deposits is due to regional differences in sulfide content of the bedrock, and pave the way for reevaluating the likelihood that early sediments preserved biosignatures from the earliest times.
\end{abstract}

(c) 2012 Elsevier Ltd. All rights reserved.

\section{INTRODUCTION}

During the last eight years, spaceborne imaging spectrometers have permitted the discovery of hydrated sulfates in different regions of Mars, including Valles Marineris and Terra Meridiani (Bibring et al., 2005; Gendrin et al., 2005; Langevin et al., 2005; Mangold et al., 2008; Massé et al., 2008; Murchie et al., 2009; Roach et al., 2010). In this last region, the Opportunity rover has carried out a detailed

\footnotetext{
* Corresponding author. Tel.: +332511253 36; fax: +3325112 5268 .

E-mail address: erwin.dehouck@univ-nantes.fr (E. Dehouck).
}

field study with direct rock analyses (Christensen et al., 2004; Clark et al., 2005; Grotzinger et al., 2005). Due to the observed enrichment in sulfate minerals - including Ca-, Mg-sulfates and jarosite (Christensen et al., 2004; Klingelhöfer et al., 2004; McLennan et al., 2005) - the superficial rock units were informally named "Burns formation" to honor Roger Burns, who predicted that ferric sulfates should occur on Mars (Burns, 1987). However, the model suggested by Burns, which involved the weathering of Fe-sulfides (Burns, 1987; Burns and Fisher, 1990a,b), has subsequently been very little explored as a formation process for the Meridiani paragenesis (Zolotov and Shock, 2005). Instead, interpretations have included: precipitation of dissolved salts in evaporating water (Squyres et al., 
2004), acid-fog alteration (Tosca et al., 2004; Berger et al., 2009), impact surge (Knauth et al., 2005), volcanism (McCollom and Hynek, 2005), or ice sheet sublimation residue (Niles and Michalski, 2009). However, although these models can explain some characteristics of the sediments, they lack experimental verifications and/or do not explain how to maintain the low $\mathrm{pH}$ required for the precipitation of jarosite.

Imaging spectrometers have also been used to look for carbonate rocks, which would be expected if an interaction between a $\mathrm{CO}_{2}$-rich atmosphere and surface water reservoirs had occurred during the early history of Mars. Although orbital data have not shown any evidence of large-scale carbonate-rich units (Bibring et al., 2005), several Mg-carbonate-bearing outcrops have been discovered in the Nili Fossae region (Ehlmann et al., 2008). More recently, other occurrences of carbonates have been reported in several places, including the landing sites of the Spirit rover (Morris et al., 2010) and the Phoenix lander (Boynton et al., 2009) and central peaks of several craters (Michalski and Niles, 2010; Wray et al., 2011).

The chemical contexts required for the formation of Fesulfates and carbonates are clearly incompatible, because acidic conditions in which Fe-sulfates are formed preclude the formation or the preservation of carbonates. Yet, carbonates in Nili Fossae probably formed during Late Noachian or Early Hesperian (Ehlmann et al., 2008; Bishop et al., 2011), a period proposed to be dominated by volcanic-driven, acidic climate conditions (Bibring et al., 2006), which should have inhibited such formation of carbonates (Fairen et al., 2004; Halevy et al., 2007). Some studies suggest that these carbonates could be the result of hydrothermal processes unrepresentative of global conditions (e.g., Brown et al., 2010); in this case, however, their preservation after emplacement in multiple locations still indicates that acidic weathering has not affected the whole planet (Ehlmann et al., 2008). In this study, we explore the hypothesis that the distribution of sulfates and carbonates has been driven by local and/or regional processes rather than global ones, as suggested by the original model of Burns. To this purpose, we have developed an experimental study designed to test the role of $\mathrm{Fe}$-sulfides in the formation of sulfates or carbonates through weathering of basaltic bedrock on Mars.

\section{BACKGROUND: SULFUR ON MARS AND ON EARTH}

Nearly all Martian data sets - including analyses of SNC (shergottites-nahklites-chassignites) meteorites, orbital and in situ analyses of soils and rocks, and geochemical models indicate that the bulk composition of Mars is enriched in sulfur compared to Earth (see the review of King and McLennan (2010)). Thus, the sulfur cycle is a key to understand the past environmental conditions of the surface of Mars. In particular, the sulfate-rich deposits first discovered through orbital data represent a unique opportunity to study the consequences of the enrichment in sulfur of the Martian crust.
Extraction of significant amounts of sulfur from the mantle by hot, Fe-rich, komatiite-like magmas is expected on ancient Mars, based on experimental data and thermochemical calculations (Burns and Fisher, 1990b; Gaillard and Scaillet, 2009; Righter et al., 2009). This led several authors to propose that the Martian sulfate-bearing deposits have been formed by acidic, $\mathrm{SO}_{2}$-driven weathering of basaltic primary rocks (Tosca et al., 2004; Golden et al., 2005; McCollom and Hynek, 2005; Bibring et al., 2006). This process would have been triggered by large volcanic emissions and would have been the dominant alteration process during a whole era, named "Theiikian" by Bibring et al. (2006).

However, the balance between the oxidized $\left(\mathrm{SO}_{2}\right)$ and reduced $\left(\mathrm{H}_{2} \mathrm{~S} /\right.$ sulfides $)$ forms of magmatic $\mathrm{S}$ is still not clearly established for Martian magmas due to uncertainties about some key parameters like composition, pressure, temperature, oxygen fugacity and water content (Carroll and Rutherford, 1985; Gaillard and Scaillet, 2009). Some clues are given by the study of the SNC meteorites, which have up to $\sim 0.2 \mathrm{wt} . \%$ of $\mathrm{S}$ (Meyer, 2008). In particular, the sulfide-bearing mineralogical assemblages (Rochette et al., 2001; Weiss et al., 2002; Lorand et al., 2005) and the low values of oxygen fugacity (Herd et al., 2002; Peslier et al., 2010) found in these rocks suggest that $\mathrm{SO}_{2}$-dominated magmas must have been rare on Mars (de Moor et al., 2011). It has also been proposed that monoclinic pyrrhotite $\left(\mathrm{Fe}_{1-x} \mathrm{~S}\right.$; $x=0-0.2$ ) could be an important magnetic mineral of the Martian crust and could explain the magnetic features observed in the Martian southern hemisphere (Rochette et al., 2001, 2003). Therefore, it seems plausible that sulfides (along with $\mathrm{H}_{2} \mathrm{~S}$ ) could be in fact the dominant form in which sulfur have reached the surface or near-surface of Mars.

On Earth, due to the lower sulfur content of the mantle and to the different conditions in which magmas form and evolve, sulfur-rich igneous rocks are not common. Hence, it is difficult to make direct analogies with Mars. However, some Fe-sulfide-rich deposits of hydrothermal origin do exist. These deposits are well studied because they contain economically interesting metals ( $\mathrm{Ni}, \mathrm{Cu}, \mathrm{Zn}$, etc.). They are known to be easily oxidized and to generate acidity as soon as they are exposed to near-surface conditions during mining or excavation (e.g., Nordstrom and Alpers, 1999; Moncur et al., 2009). The secondary minerals produced by sulfide-derived, acidic waters are also well studied and mainly consist of various sulfates and $\mathrm{Fe}$-(oxy)hydroxides (e.g., Bladh, 1982; Nordstrom and Alpers, 1999). Some examples of these deposits, like the Río Tinto basin in southwestern Spain, have been already proposed as terrestrial analogs for the Burns formation of Meridiani Planum (Fernandez-Remolar et al., 2005). Therefore, sulfide-weathering could be a relevant process to explain the "theiikian" mineralogy of Mars, but it should be demonstrated first that similar reactions can happen under Martian conditions, i.e. with nearly no atmospheric $\mathrm{O}_{2}$. 


\section{MATERIAL AND METHODS}

\subsection{Initial material}

\subsubsection{Description}

We used as initial material several primary basaltic minerals previously observed on Mars (Chevrier and Mathé, 2007) and in SNC meteorites (Papike et al., 2009): olivine (two different ones, O11 and O12), clinopyroxene (CPx) and orthopyroxene (OPx). Both $\mathrm{Ol1}$ and $\mathrm{Ol} 2$ were $\mathrm{Mg}$-rich, with a composition of forsterite $\sim 90\left(\mathrm{Fo}_{\sim 90}\right)$ verified by scanning electron microscopy (SEM). O11 was extracted from a dunite coming from Massif Central, France and contained $\sim 8 \%$ of orthopyroxene, whereas $\mathrm{O} 12$ consisted of monocrystals coming from Pakistan and was nearly pure. CPx was diopside from Vesuvium, Italy, with a formula of $\mathrm{Ca}_{0.9} \mathrm{Mg}_{1.0} \mathrm{Fe}_{0.1}\left(\mathrm{Si}_{1.9} \mathrm{Al}_{0.1}\right) \mathrm{O}_{6}$ determined by SEM. OPx was enstatite from Ronda, Spain, with a formula of $\mathrm{Ca}_{0.1} \mathrm{Mg}_{1.8} \mathrm{Fe}_{0.3} \mathrm{Si}_{1.9} \mathrm{O}_{6}$, associated with minor amphibole $(\sim 5 \%)$. The precise chemical compositions are presented in Table 1.

For the Fe-sulfide, we chose natural hexagonal pyrrhotite (HPo) $\mathrm{Fe}_{0.9} \mathrm{~S}$ from Ducktown Mine, Tennessee (Carpenter, 1974), which was already used for similar studies (Chevrier et al., 2004, 2006). Pyrrhotite is known to be abundant in some SNC meteorites (Rochette et al., 2001; Lorand et al., 2005) and is thought to exist in near-surface deposits on Mars (Burns and Fisher, 1990b; Rochette et al., 2003). It is also the most easily-oxidized sulfide in terrestrial conditions (Moncur et al., 2009), which could be an advantage to highlight slow weathering processes. Associated impurities with our pyrrhotite were: chalcopyrite $(\sim 2 \%)$, amphibole $(\sim 2-5 \%)$, mica $(\sim 2 \%)$ and talc $(\sim 1 \%)$. These impurities explain the presence of minor $\mathrm{Si}, \mathrm{Ca}$ and $\mathrm{Mg}$ in the chemical analyses (Table 1).

Table 1

Chemistry of the natural mineral samples used as initial materials of the experiment. LOD, limit of detection; LOI, loss on ignition.

\begin{tabular}{llllll}
\hline wt. $\%)$ & Ol1 & Ol2 & CPx & OPx & HPo \\
\hline $\mathrm{SiO}_{2}$ & 42.81 & 40.58 & 52.08 & 55.52 & 3.63 \\
$\mathrm{Al}_{2} \mathrm{O}_{3}$ & 0.41 & $<$ LOD & 2.98 & 1.09 & 0.24 \\
$\mathrm{FeO}$ & 8.75 & 9.22 & 3.69 & 9.99 & - \\
$\mathrm{MnO}$ & 0.12 & 0.15 & 0.09 & 0.18 & 0.17 \\
$\mathrm{MgO}$ & 47.46 & 49.80 & 16.06 & 31.97 & 1.33 \\
$\mathrm{CaO}$ & 0.42 & 0.06 & 23.99 & 0.85 & 1.28 \\
$\mathrm{Na} 2 \mathrm{O}$ & $<$ LOD & $<$ LOD & 0.51 & $<$ LOD & 0.01 \\
$\mathrm{~K}_{2} \mathrm{O}$ & $<$ LOD & $<$ LOD & 0.43 & $<$ LOD & 0.06 \\
$\mathrm{TiO}_{2}$ & 0.01 & 0.00 & 0.36 & 0.09 & $<$ LOD \\
$\mathrm{P}_{2} \mathrm{O}_{5}$ & $<$ LOD & $<$ LOD & $<$ LOD & 0.05 & 0.01 \\
$\mathrm{LOI}$ & 0.00 & 0.05 & 0.58 & 0.10 & - \\
$\mathrm{CO}_{2}$ & - & - & - & - & 0.72 \\
$\mathrm{~S}$ & - & - & - & - & 35.56 \\
$\mathrm{Fe}$ & - & - & - & - & 54.07 \\
$\mathrm{Ni}$ & - & - & - & - & $<$ LOD \\
$\mathrm{Cu}$ & - & - & - & - & 0.83 \\
$\mathrm{Zn}$ & - & - & - & - & 0.16 \\
$\mathrm{Total}$ & 99.98 & 99.86 & 100.77 & 99.84 & 98.07 \\
\hline
\end{tabular}

\subsubsection{Preparation}

All the minerals were manually ground in an agate mortar and sieved to a grain size below $63 \mu \mathrm{m}$. The powders were then washed using a dilute $\mathrm{HCl}$ solution. The silicate powders were also cleaned using the CBD (citrate-bicarbonate-dithionite) method, which ensures the removal of any $\mathrm{Fe}$-(oxy)hydroxide possibly present in the initial material (Mehra and Jackson, 1960). The CBD method was not applied to the pyrrhotite powder, because it naturally contains some $\mathrm{Fe}^{3+}$. The powders were finally rinsed with deionized water, centrifuged and dried at $50{ }^{\circ} \mathrm{C}$.

Three grams samples were prepared as follows: two of each silicate alone (O11, O12, CPx and OPx) and two mixtures of each silicate - besides $\mathrm{Ol} 2$, due to limited quantity available - equally mixed with pyrrhotite (O11-HPo, CPx$\mathrm{HPo}$ and $\mathrm{OPx}-\mathrm{HPo})$. This high proportion of sulfide (50 wt.\%) was not intended to be realistic, but to enhance weathering processes and hence to facilitate the analysis of the secondary minerals, given the uncertainties about reaction rates in our $\mathrm{CO}_{2}$-dominated atmospheres. The samples were finally laid out in small glass cups awaiting the start of the experiment.

\subsection{Experimental procedures}

Our experimental apparatus was similar to the one already used by Chevrier et al. $(2004,2006)$ and is described in Fig. 1. It consisted of two vacuum desiccators with gas entries/outlets, allowing pumping and exchange of the internal atmosphere. We used this to create in each desiccator a $\mathrm{CO}_{2}$-dominated, humid atmosphere in which solid samples can be weathered without direct contact with the liquid body. Weathering thus needed the condensation of thin liquid films, resulting in low liquid-to-rock ratios. The different steps of the protocol are detailed in the following paragraph.

First, the bottom of the desiccators was filled with $1 \mathrm{~L}$ of deionized water for the first one and with $1 \mathrm{~L}$ of a solution containing $\sim 33 \%$ of $\mathrm{H}_{2} \mathrm{O}_{2}$ for the second one. Then, the samples (silicates alone and silicate/sulfide mixtures) were placed above the liquid: a duplicate was put inside the $\mathrm{H}_{2} \mathrm{O}_{2}$-free desiccator and the other duplicate in the $\mathrm{H}_{2} \mathrm{O}_{2}$ bearing one (the suffix " $\mathrm{H}_{2} \mathrm{O}$ " or " $\mathrm{H}_{2} \mathrm{O}_{2}$ " was added to the name of each sample to distinguish the two duplicates). Finally, the desiccators were closed and their internal atmosphere was purged and replaced by gaseous $\mathrm{CO}_{2}$. This step was done twice to obtain an initial atmosphere composed of $>99 \% \mathrm{CO}_{2}$. The internal pressure was set slightly under the atmospheric pressure ( 0.8 bar) to ensure an efficient tightening of the desiccators' seals and to prevent by this way any accidental opening. After these initial operations, the experimental apparatus was left at ambient temperature $(\sim 15$ $20^{\circ} \mathrm{C}$ ), allowing evaporation of the liquid phase to reach $\mathrm{H}_{2} \mathrm{O}$ or $\mathrm{H}_{2} \mathrm{O}+\mathrm{H}_{2} \mathrm{O}_{2}$ vapor saturation. The experiment lasted 4 years, from September 2005 to September 2009.

As the composition of the atmosphere is a key parameter controlling the reaction pathways, it was important to maintain it throughout the experiment. Two potential sources of contamination existed: (1) room air outside the apparatus and (2) gases dissolved in the water put at the 


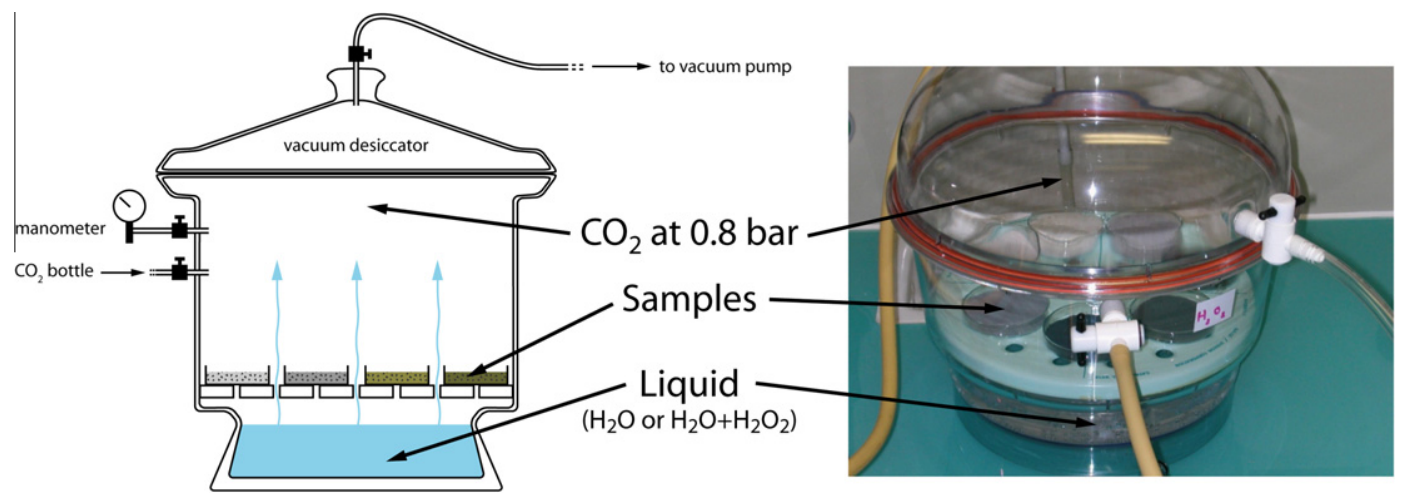

Fig. 1. Schematic diagram and photograph of one vacuum desiccator used in the experiment (for clarity, the arrangement of the access ports is slightly different in the diagram). The solid samples were placed in small glass cups on the white support in the middle and the liquid phase $\left(\mathrm{H}_{2} \mathrm{O}\right.$ alone or $\left.\mathrm{H}_{2} \mathrm{O}+\mathrm{H}_{2} \mathrm{O}_{2}\right)$ was put below. The access ports remained closed when not used. The desiccator is about $30 \mathrm{~cm}$ high and $25 \mathrm{~cm}$ in diameter; the internal volume is $15 \mathrm{~L}$. The complete apparatus consisted of two desiccators (see text).

bottom of the desiccators. Concerning (1), although our equipment did not allow direct sampling of the atmosphere inside the desiccators, previous experiments using the same apparatus (Chevrier et al., 2004, 2006) have shown that vacuum desiccators were effectively airtight at a year scale. This was verified again here by checking at regular intervals the internal pressure of the desiccators using a manometer. Given the longer duration of this experiment, we also decided to exchange the internal atmosphere approximately every six months in order to anticipate any contamination. Concerning (2), Chevrier et al. (2004, 2006) have shown that $\mathrm{O}_{2}$ initially dissolved in water was in almost negligible amount compared to the total mass of samples, particularly since initial pumping partially removes dissolved gases. Here, we did not open the desiccators during the whole experiment - no sampling was done - in order to prevent reequilibration of water with room air and any other perturbation.

At the end of the experiment, the desiccators were opened and all the samples were oven-dried during a whole night in order to completely stop the weathering reactions before the start of the analyses.

\subsection{Experimental rationale}

The observation of geomorphic features associated with flowing water (valley networks, outflow channels, deltas, terraces; e.g., Ori et al., 2000; Carr and Head, 2010) and the widespread detection of hydrated minerals (Bibring et al., 2006; Murchie et al., 2009) on Mars suggest the presence of a warmer and more humid atmosphere during the Noachian and Hesperian periods. If this early atmosphere was dominated by $\mathrm{CO}_{2}$ as it is today, then the atmospheric pressure must have been higher to sustain liquid water (Pollack et al., 1987; Phillips et al., 2001). How high exactly the pressure was remains a subject of debate, as well as the need for other gases $\left(\mathrm{SO}_{2}, \mathrm{CH}_{4}\right.$; Halevy et al., 2007; Johnson et al., 2009) or other factors (impacts, volcanism; Carr and Head, 2010; and references therein). Here, we choose not to use $\mathrm{SO}_{2}$ to avoid confusion in our results between sulfur coming from $\mathrm{SO}_{2}$ and sulfur coming from sulfides.
The effect of this gas on weathering will be explored in another study currently in preparation. We did not use $\mathrm{CH}_{4}$ for safety reasons. Near-ambient pressures are common in experimental simulations of Martian weathering processes (e.g., Bullock et al., 2004; Schröder et al., 2004). In our case, the use of vacuum desiccators has the advantage to allow a slightly lower, probably more realistic value for the atmospheric pressure.

The use of $\mathrm{H}_{2} \mathrm{O}_{2}$ is justified by its recent detection in the Martian atmosphere (Clancy et al., 2004), where it is produced by the photochemistry of $\mathrm{H}_{2} \mathrm{O}$ (the reactions involved are detailed by Bates and Nicolet, 1950). This molecule is also thought to be responsible for the oxidizing properties of the regolith analyzed by the Viking landers (Bullock et al., 1994; Zent, 1998; Yen et al., 2000; Hurowitz et al., 2007; Navarro-Gonzalez et al., 2010). Due to the absence of an ozone layer on Mars, it could have been produced by the same reactions and in greater quantities in the past, if the early Martian atmosphere was indeed enriched in $\mathrm{H}_{2} \mathrm{O}$. Hence, $\mathrm{H}_{2} \mathrm{O}_{2}$ could have played a non-negligible role in the weathering processes. Even in favorable conditions, however, a volume mixing ratio of $33 \% \mathrm{H}_{2} \mathrm{O}_{2}$ remains unrealistic (Liang et al., 2006): the goal here was mainly to highlight its effects. $\mathrm{H}_{2} \mathrm{O}_{2}$ is known to spontaneously disproportionate to $\mathrm{H}_{2} \mathrm{O}$ and $\mathrm{O}_{2}$, but this process was limited in our experiment because it was conducted at low temperature and in the dark. Although some free $\mathrm{O}_{2}$ probably formed by this way, we have considered that it was not an issue for the interpretation of our results given that the coexistence of the two species is inevitable in natural systems and that it does not affect the global redox state of the system. The initial amount of liquid $\mathrm{H}_{2} \mathrm{O}_{2}$ put in the desiccators ensured that $\mathrm{H}_{2} \mathrm{O}_{2}$ vapor remains available until the end of the experiment. The use of poorly- and highly-oxidizing atmospheres will allow to compare the efficiency of sulfide weathering in different possible past Martian conditions.

Though modeling a possible ancient Martian atmosphere enriched in $\mathrm{CO}_{2}$ and $\mathrm{H}_{2} \mathrm{O}$, our experimental conditions (including temperature) were not chosen to exactly mimic the weathering on early Mars, what would be challenging given the lack of knowledge and consensus about 
the environmental setting at this time. Instead, the aim was to highlight the role of several parameters $\left(\mathrm{CO}_{2}\right.$-rich atmosphere, oxidant species, sulfide content) in the weathering reactions. These conditions also permit to increase reaction rates and hence to keep the timeframe of the experiment reasonable.

\subsection{Analytical methods}

Since all the minerals used in the experiment were of natural origin, ICP-OES (Inductively Coupled Plasma-Optical Emission Spectrometry) chemical analyses were ordered from the Service d'Analyse des Roches et des Minéraux of the Centre de Recherches Pétrographiques et Géochimiques (SARM-CRPG), Vandœuvre-lès-Nancy, France (Table 1).

The mineralogy of the samples was characterized before and after the experiment by X-ray diffraction (XRD) using a Panalytical ${ }^{\circledR}$ X'Pert Pro MPD diffractometer equipped with a cobalt source. Measurements were done at an intensity of $40 \mathrm{~mA}$ and a voltage of $40 \mathrm{kV}$ between $2 \theta=4^{\circ}$ and $78^{\circ}$, with steps of $0.033^{\circ}$. The counting time per step was set at $3 \mathrm{~s}$ (total acquisition time: $\sim 2 \mathrm{~h}$ ), except for the three silicate/sulfide mixtures weathered in the $\mathrm{H}_{2} \mathrm{O}_{2}$-free atmosphere, for which the counting time per step was set at $22 \mathrm{~s}$ (total acquisition time: $\sim 14 \mathrm{~h}$ ). Mineral phases were then identified using the $\mathrm{EVA}^{\circledR}$ software and the PDF 2 database provided by the International Centre for Diffraction Data (ICDD; http://www.icdd.com/). When needed, the weathered samples were gently re-ground in an agate mortar before being analyzed in order to suppress the fine crust formed by secondary phases and hence ensure homogenization (both in composition and grain size) and limit preferred orientations (Cullity, 1956).

XRD semi-quantitative analyses were achieved by the Reference Intensity Ratio (RIR) method (Hillier, 2000; and references therein) using the EVA software. This method is based on the measurement of intensities of the diffraction peaks above background combined with the use of ICDD quantitative coefficients taking into account the diffraction abilities of each mineral. The main limitations of this method come from preferred orientations of elongated crystals, presence of poorly-crystallized or amorphous phases and extinction effects (Cullity, 1956). Poorly-crystallized phases show patterns with broader peaks than wellcrystallized ones and, as a consequence, they tend to be underestimated using the RIR method (because it is based on the intensity of the peaks and not their area). Despite the limitations mentioned, Hillier (2000) demonstrated that the RIR method can give accurate results. In favorable conditions, the errors are $\sim 10 \%$ relative or better (Hillier, 2000; and references therein). However, given the complexity of our samples due to numerous phases (peaks overlapping) and to olivine and pyroxene minerals having solid solutions, precise RIR quantification presented here was achieved only on well-crystallized secondary minerals (namely, elemental sulfur and sulfates) and a higher relative error of $20 \%$ was used. Reference patterns are of importance to avoid further uncertainties, so we used only patterns labeled as calculated (from structure parameters) or as high/good quality in the database.
Near-infrared spectra of the samples were acquired using a Nicolet ${ }^{\circledR} 5700$ Fourier transform infrared spectrometer (FTIR) equipped with a white light source, a $\mathrm{CaF}_{2}$ beam splitter and a DTGS detector. For each sample, a part of the powder was prepared to obtain a flat surface and placed inside the FTIR chamber which was then purged during two minutes with dry and $\mathrm{CO}_{2}$-free air. Spectra presented in this paper are the average of 200 measurements in the wavelength range of $1-5 \mu \mathrm{m}$ with a resolution of $4 \mathrm{~cm}^{-1}$. Background spectra were acquired using a Labsphere ${ }^{\circledR}$ Infragold reference. Spectra acquisition and background correction were done using the OMNIC ${ }^{\circledR}$ software and spectra analyses and comparisons were done using the ENVI $^{\circledR}$ software.

Lastly, scanning electron microscopy (SEM) observations were performed at the Institut des Matériaux Jean Rouxel (Nantes, France) using a JEOL ${ }^{\circledR} 5800 \mathrm{LV}$ microscope coupled with an EDS analytical system. For each sample, a part of the powder was placed on a carbon tape and was carbon-coated before its introduction inside the instrument. Observations were made at a voltage of 15 or $20 \mathrm{kV}$.

\section{RESULTS}

\subsection{Mineralogy of the weathered samples}

Table 2 and Fig. 2 summarize initial and secondary phases detected by XRD in the silicate-only and silicate/sulfide samples at the end of the experiment. Table 2 introduces a distinction between minor, intermediate and major phases. Examples of diffraction patterns are shown in Fig. 3 and the complete series can be found in the electronic annex (Fig. S1).

\subsubsection{Silicate-only samples}

Olivine: The X-ray diffraction patterns of $\mathrm{Ol1}-\mathrm{H}_{2} \mathrm{O}$, $\mathrm{O} 11-\mathrm{H}_{2} \mathrm{O}_{2}, \mathrm{Ol} 2-\mathrm{H}_{2} \mathrm{O}$ and $\mathrm{O} 2-\mathrm{H}_{2} \mathrm{O}_{2}$ (weathered) samples are very similar to those of unweathered $\mathrm{Ol1}$ and $\mathrm{Ol} 2$ (Fig. 3 and S1), indicating very limited alteration both in the $\mathrm{H}_{2} \mathrm{O}$-bearing atmosphere and in the $\mathrm{H}_{2} \mathrm{O}+\mathrm{H}_{2} \mathrm{O}_{2}$-bearing one. The main peaks are attributed to initial minerals, forsterite and orthopyroxene. In addition to these ones, two small peaks are found at $2 \theta=15.8^{\circ}$ and $39.9^{\circ}$ in $\mathrm{O} 11-\mathrm{H}_{2} \mathrm{O}_{2}, \mathrm{O} 2-\mathrm{H}_{2} \mathrm{O}$ and $\mathrm{O} 12-\mathrm{H}_{2} \mathrm{O}_{2}$ samples, revealing the presence of a newly formed $\mathrm{Mg}$-bearing carbonate, nesquehonite $\mathrm{Mg}\left(\mathrm{HCO}_{3}\right)(\mathrm{OH}) \cdot 2 \mathrm{H}_{2} \mathrm{O}$. The estimated quantity of nesquehonite in the three samples is low $(<5 \mathrm{vol}$ $\%$ ). Due to this limited quantity, nesquehonite was not found using SEM.

Clinopyroxene: All the diffraction peaks observed in the $\mathrm{CPx}-\mathrm{H}_{2} \mathrm{O}$ and $\mathrm{CPx}-\mathrm{H}_{2} \mathrm{O}_{2}$ samples are attributed to initial diopside. No secondary phase was found either by SEM.

Orthopyroxene: All the diffraction peaks observed in the $\mathrm{OPx}-\mathrm{H}_{2} \mathrm{O}$ and $\mathrm{OPx}-\mathrm{H}_{2} \mathrm{O}_{2}$ samples are attributed to initial enstatite and amphibole. No secondary phase was found either by SEM.

\subsubsection{Silicate/sulfide mixtures \\ Olivine + pyrrhotite: XRD data of the Ol1- $\mathrm{HPo}-\mathrm{H}_{2} \mathrm{O}$ and $\mathrm{Ol1}-\mathrm{HPo}-\mathrm{H}_{2} \mathrm{O}_{2}$ (weathered) samples show an}


Table 2

Summary of initial and secondary phases observed after 4 years of weathering, based on semi-quantitative XRD analyses (see Section 3.4). A distinction is made between minor ( $<5 \mathrm{vol} \%$; " + "), intermediate ("++") and major phases ( $>30 \mathrm{vol} \%$; " +++ "). Newly formed phases are indicated by an asterisk. Ol, olivine; $\mathrm{CPx}$, diopside; OPx, enstatite; $\mathrm{HPo}$, pyrrhotite; $\mathrm{H}_{2} \mathrm{O}$, atmosphere containing water vapor; $\mathrm{H}_{2} \mathrm{O}_{2}$, atmosphere containing water and hydrogen peroxide vapor.

\begin{tabular}{|c|c|c|c|c|c|c|c|c|}
\hline \multirow[t]{2}{*}{ Without sulfide } & \multicolumn{2}{|l|}{$\mathrm{Ol1}$} & \multicolumn{2}{|l|}{$\mathrm{O} 12$} & \multicolumn{2}{|l|}{$\mathrm{CPx}$} & \multicolumn{2}{|l|}{ OPx } \\
\hline & $\mathrm{H}_{2} \mathrm{O}$ & $\mathrm{H}_{2} \mathrm{O}_{2}$ & $\mathrm{H}_{2} \mathrm{O}$ & $\mathrm{H}_{2} \mathrm{O}_{2}$ & $\mathrm{H}_{2} \mathrm{O}$ & $\mathrm{H}_{2} \mathrm{O}_{2}$ & $\mathrm{H}_{2} \mathrm{O}$ & $\mathrm{H}_{2} \mathrm{O}_{2}$ \\
\hline $\begin{array}{l}\text { Olivine } \\
\text { Clinopyroxene }\end{array}$ & +++ & +++ & +++ & +++ & +++ & +++ & & \\
\hline $\begin{array}{l}\text { Orthopyroxene } \\
\text { Amphibole }\end{array}$ & ++ & ++ & & & & & $\begin{array}{l}+++ \\
+\end{array}$ & $\begin{array}{l}+++ \\
+\end{array}$ \\
\hline${ }^{*}$ Nesquehonite & & + & + & + & & & & \\
\hline \multirow[t]{2}{*}{ With sulfide } & \multicolumn{2}{|c|}{ Ol1-HPo } & \multicolumn{2}{|c|}{$\mathrm{Ol} 2-\mathrm{HPo}^{\mathrm{a}}$} & \multicolumn{2}{|c|}{$\mathrm{CPx}-\mathrm{HPo}$} & \multicolumn{2}{|c|}{$\mathrm{OPx}-\mathrm{HPo}$} \\
\hline & $\mathrm{H}_{2} \mathrm{O}$ & $\mathrm{H}_{2} \mathrm{O}_{2}$ & $\mathrm{H}_{2} \mathrm{O}$ & $\mathrm{H}_{2} \mathrm{O}_{2}$ & $\mathrm{H}_{2} \mathrm{O}$ & $\mathrm{H}_{2} \mathrm{O}_{2}$ & $\mathrm{H}_{2} \mathrm{O}$ & $\mathrm{H}_{2} \mathrm{O}_{2}$ \\
\hline Olivine & +++ & +++ & & & & & & \\
\hline $\begin{array}{l}\text { Clinopyroxene } \\
\text { Orthopyroxene }\end{array}$ & + & + & & & +++ & +++ & +++ & +++ \\
\hline Amphibole & + & + & & & ++ & ++ & + & + \\
\hline Talc + mica & + & & & & + & & + & + \\
\hline Pyrrhotite & + & + & & & + & + & ++ & + \\
\hline${ }^{*}$ Elemental sulfur & ++ & ++ & & & ++ & ++ & ++ & ++ \\
\hline *Gypsum & ++ & ++ & & & ++ & ++ & ++ & ++ \\
\hline${ }^{*}$ Hexahydrite & ++ & ++ & & & + & + & + & + \\
\hline * Jarosite & & & & & + & ++ & & ++ \\
\hline${ }^{*}$ Goethite & ++ & ++ & & & ++ & ++ & ++ & ++ \\
\hline${ }^{*}$ Hematite & & ++ & & & & & & \\
\hline
\end{tabular}

${ }^{a}$ It was not possible to prepare O12-HPo mixtures, as only a limited quantity of this olivine was available.

important mineralogical diversity. Initial forsterite and orthopyroxene are detected. Pyrrhotite is identified as well, but the estimated quantity is very low $(<5 \mathrm{vol} \%)$ compared to its initial proportion (50 wt. \%). A peak located at $2 \theta=11.0^{\circ}$ indicates the presence of minor talc in $\mathrm{Ol1}-$ $\mathrm{HPo}-\mathrm{H}_{2} \mathrm{O}$ sample, but this peak is absent in the Ol1$\mathrm{HPo}-\mathrm{H}_{2} \mathrm{O}_{2}$ sample. Two other peaks at $2 \theta=11.4^{\circ}$ and $12.2^{\circ}$ indicate that amphibole survives in the two types of atmosphere. Chalcopyrite and mica, the two other impurities associated with initial pyrrhotite, are not detected anymore.

The secondary phases identified are elemental sulfur $\mathrm{S}^{0}$, hexahydrite $\mathrm{MgSO}_{4} \cdot 6 \mathrm{H}_{2} \mathrm{O}$, gypsum $\mathrm{CaSO}_{4} \cdot 2 \mathrm{H}_{2} \mathrm{O}$, and goethite $\mathrm{Fe}^{3+} \mathrm{O}(\mathrm{OH})$. Hematite $\mathrm{Fe}^{3+}{ }_{2} \mathrm{O}_{3}$ is also identified in the Ol1- $\mathrm{HPo}-\mathrm{H}_{2} \mathrm{O}_{2}$ sample, on the basis of the peak at $2 \theta=28.1^{\circ}$.

SEM observations revealed the presence of partially dissolved olivine crystals (Fig. S2A), as well as remaining pyrrhotite. Hexahydrite was found as poorly-crystallized crystals forming columnar or "cauliflower-like" aggregates (Fig. S2B) and sometimes showed desiccation cracks probably due to the vacuum environment of the instrument. Gypsum crystals varied in size from several micrometers to several tens of micrometers.

Clinopyroxene + pyrrhotite: As the olivine/pyrrhotite mixtures, $\mathrm{CPx}-\mathrm{HPo}-\mathrm{H}_{2} \mathrm{O}$ and $\mathrm{CPx}-\mathrm{HPo}-\mathrm{H}_{2} \mathrm{O}_{2}$ show diffraction peaks of various minerals, including the initial silicate (here diopside). Pyrrhotite and associated amphibole are detected in small quantities $(<5 \mathrm{vol} \%)$. Talc is again present in the $\mathrm{H}_{2} \mathrm{O}$-bearing atmosphere and absent in the $\mathrm{H}_{2} \mathrm{O}+\mathrm{H}_{2} \mathrm{O}_{2}$-bearing one. Mica is identified by a peak at $2 \theta=7.2^{\circ}$ in both atmospheres.

In addition to elemental sulfur, gypsum, hexahydrite and goethite, neoformed jarosite is identified in the two samples by the peaks at $2 \theta=17.4^{\circ}, 20.2^{\circ}, 28.3^{\circ}, 30.2^{\circ}$ and $30.7^{\circ}$. No hematite is identified here. Note that, contrary to olivine/pyrrhotite mixtures, hexahydrite is only minor here (Table 2).

SEM observations revealed the presence of automorph crystals of gypsum measuring several tens of micrometers in $\mathrm{CPx}-\mathrm{HPo}-\mathrm{H}_{2} \mathrm{O}$ (Fig. 4A) but only several micrometers in $\mathrm{CPx}-\mathrm{HPo}-\mathrm{H}_{2} \mathrm{O}_{2}$. Jarosite was found in the form of hexagonal crystals measuring several micrometers, isolated or aggregated (Figs. 4B and S2C). Goethite appeared in small crystals $(<0.5 \mu \mathrm{m})$ covering other minerals or aggregated into "balls" of several micrometers (Fig. 4C).

Orthopyroxene + pyrrhotite: The diffraction patterns of weathered orthopyroxene/pyrrhotite mixtures show peaks attributed to initial enstatite and amphibole. Pyrrhotite is detected in both atmospheres, but in greater quantity in the $\mathrm{H}_{2} \mathrm{O}$-bearing one ("intermediate" in Table 2) compared to the other silicate/sulfide mixtures. The peak attributed to talc at $2 \theta=11.0^{\circ}$ is identified in both atmospheres. The one attributed to mica at $2 \theta=7.2^{\circ}$ is present only in the $\mathrm{OPx}-$ $\mathrm{HPo}-\mathrm{H}_{2} \mathrm{O}$ sample.

Elemental sulfur, gypsum, hexahydrite and goethite are found in the two samples. In addition, $\mathrm{OPx}-\mathrm{HPo}-\mathrm{H}_{2} \mathrm{O}_{2}$ also contains a significant amount of jarosite (Table 2). 

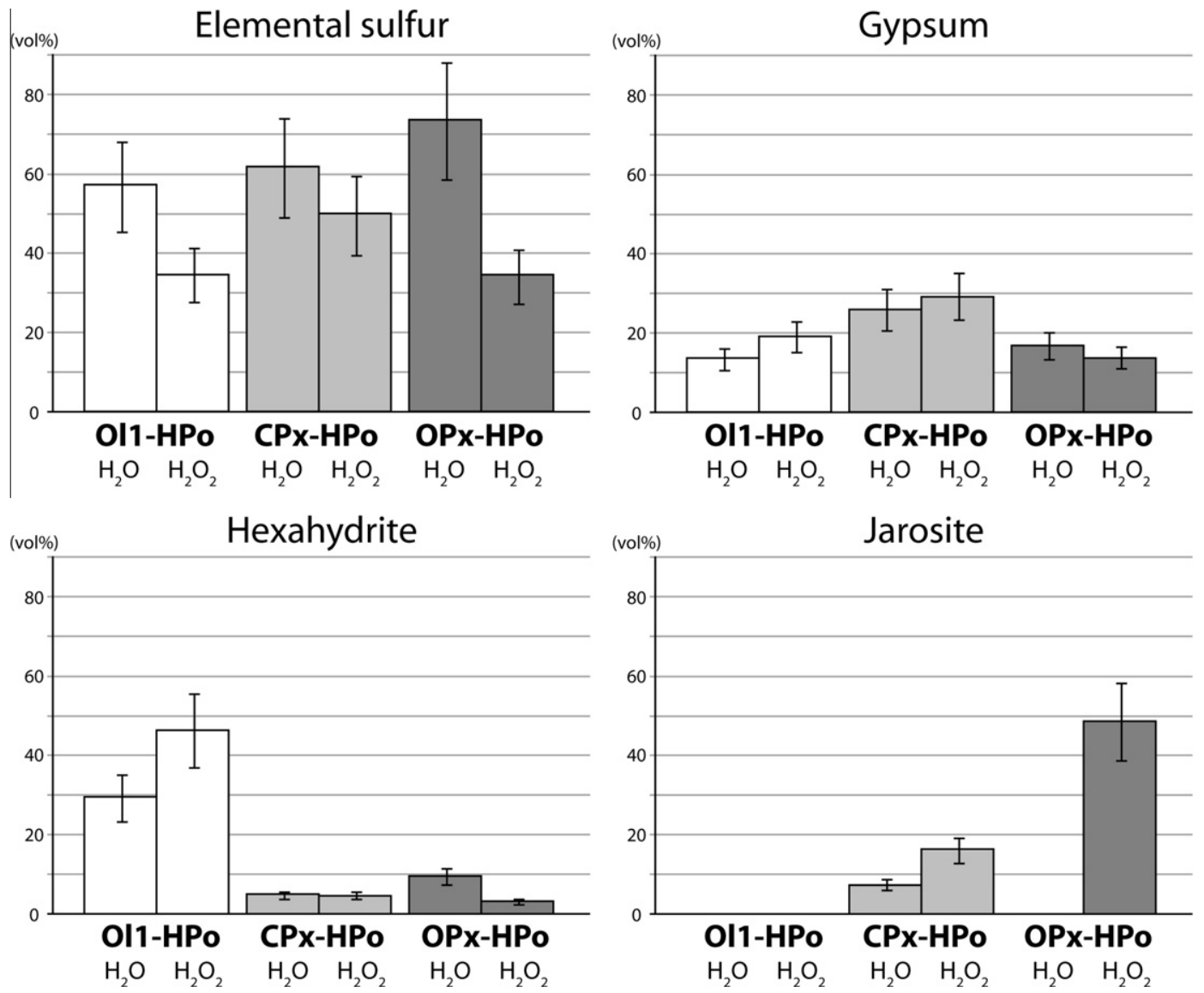

Fig. 2. Relative abundances of the sulfur-bearing secondary phases in weathered silicate/sulfide mixtures, derived from XRD data (see Section 3.4). Values are normalized to $100 \%$ for each sample. Error bars are $20 \%$ relative. Clear tendencies can be observed: relative to sulfates, elemental sulfur is always lower in samples weathered in the $\mathrm{H}_{2} \mathrm{O}+\mathrm{H}_{2} \mathrm{O}_{2}$-bearing atmosphere; hexahydrite is predominant in olivine/ pyrrhotite mixtures but minor in pyroxene/pyrrhotite mixtures; gypsum does not present such discrepancy, but is slightly higher in the clinopyroxene/pyrrhotite mixtures; jarosite is only present in pyroxene/pyrrhotite mixtures. Goethite and hematite are not included because the RIR method tends to underestimate their abundances due to their broad diffraction peaks.

Again, contrary to olivine/pyrrhotite mixtures, hexahydrite is only minor here.

SEM observations revealed the presence of automorph crystals of gypsum measuring several tens of micrometers (Fig. S2D). Unaltered enstatite, amphibole and pyrrhotite were also found, especially in the $\mathrm{OPx}-\mathrm{HPo}-\mathrm{H}_{2} \mathrm{O}$ sample.

\subsubsection{Synthesis}

Despite the 4-year duration of the experiment, the samples without sulfide underwent only minor alteration. Both pyroxenes, in particular, appear unaffected in the XRD data. The only secondary phase found is the Mg-carbonate nesquehonite $\mathrm{Mg}\left(\mathrm{HCO}_{3}\right)(\mathrm{OH}) \cdot 2 \mathrm{H}_{2} \mathrm{O}$, detected in small quantities $(<5 \mathrm{vol} \%)$ in three olivine samples.

In contrast, mixtures with pyrrhotite show extensive weathering: all samples produced several secondary phases, including elemental sulfur, hydrated sulfates and Fe(oxy)hydroxides. No carbonate was formed here. Elemental sulfur $\mathrm{S}^{0}$ appeared in all samples, as did gypsum Ca$\mathrm{SO}_{4} \cdot 2 \mathrm{H}_{2} \mathrm{O}$ and hexahydrite $\mathrm{MgSO}_{4} \cdot 6 \mathrm{H}_{2} \mathrm{O}$. The quantity of this last mineral is strongly correlated with the chemistry of the initial silicate: it is only minor in the pyroxene sam- ples, but is observed in larger quantities in the olivine samples (Table 2 and Fig. 2), which have the higher Mg content (Table 1). Although less obvious, gypsum is slightly more abundant in the clinopyrexene samples (Fig. 2), which have the higher $\mathrm{Ca}$ content (Table 1). Jarosite $\left(\mathrm{K}, \mathrm{Na}, \mathrm{H}_{3} \mathrm{O}\right)^{+} \mathrm{Fe}^{3+}{ }_{3}\left(\mathrm{SO}_{4}\right)_{2}(\mathrm{OH})_{6}$ is observed in three samples of pyroxene but not in any samples of olivine. Goethite $\mathrm{Fe}^{3+} \mathrm{O}(\mathrm{OH})$ is present in all samples and hematite $\mathrm{Fe}^{3+}{ }_{2} \mathrm{O}_{3}$ in only one $\left(\mathrm{Oll}-\mathrm{HPo}-\mathrm{H}_{2} \mathrm{O}_{2}\right)$.

A plot of the relative abundances of the sulfur-bearing secondary phases (Fig. 2) shows that for each type of silicate/sulfide mixture, elemental sulfur is always lower relative to sulfates in the $\mathrm{H}_{2} \mathrm{O}+\mathrm{H}_{2} \mathrm{O}_{2}$-bearing atmosphere than in the $\mathrm{H}_{2} \mathrm{O}$-bearing one. The $\mathrm{H}_{2} \mathrm{O}+\mathrm{H}_{2} \mathrm{O}_{2}$-bearing atmosphere favors the formation of sulfates at the expense of elemental sulfur.

Pyrrhotite is identified in all the weathered mixtures, but the final amounts are very low (typically $<5$ vol \%) compared to the initial ones. The only exception is the $\mathrm{OPx}-\mathrm{HPo}-\mathrm{H}_{2} \mathrm{O}$ sample, where $\sim 20$ vol $\%$ of pyrrhotite was remaining at the end of the experiment. The reason for this difference is not fully understood, but it could 


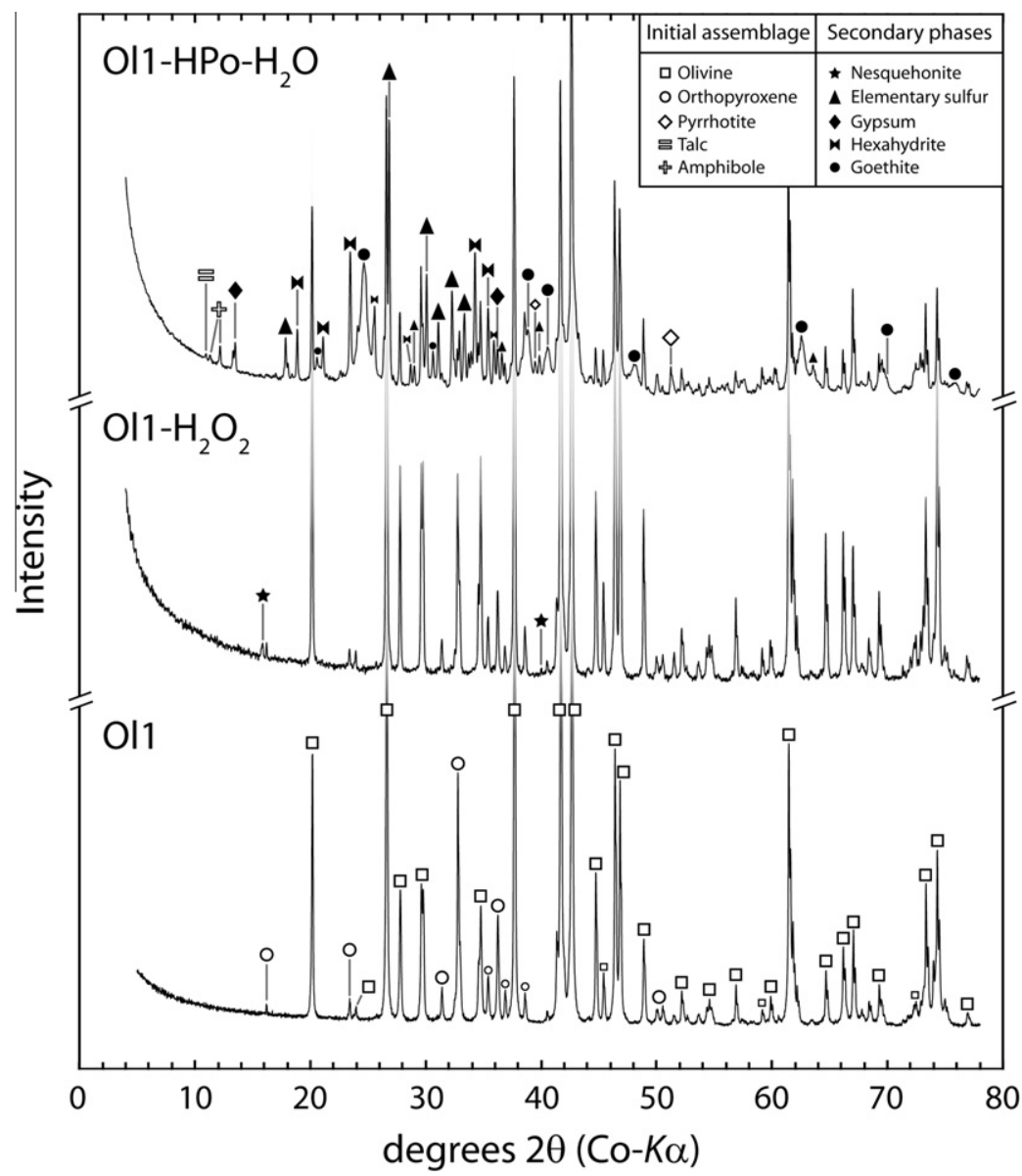

Fig. 3. X-ray diffraction patterns of Ol1-HPo- $\mathrm{H}_{2} \mathrm{O}$ (top) and $\mathrm{Ol1}-\mathrm{H}_{2} \mathrm{O}_{2}$ (middle) samples. Oll before weathering is shown for comparison (bottom). Empty and filled symbols indicate initial and secondary minerals, respectively.

be explained by a difference in grain size due to manual grinding.

Finally, it's worth reminding that XRD is mainly focused on the detection of crystallized phases. Amorphous phases like silica or glass produce a very broad "hump" instead of multiple, well-defined peaks (Cullity, 1956) and thus are more difficult to detect, especially in complex assemblages like those studied here. As a result, small abundances of amorphous phases cannot be entirely ruled out by this method, as discussed below. However, in most cases, the secondary phases were sufficiently abundant and wellcrystallized to be easily recognized by scanning electron microscopy (SEM; Figs. 4 and S2).

\subsection{Near-infrared spectroscopy}

In order to make comparisons with the observations made on Mars, we acquired infrared reflectance spectra of both our initial and final samples (Fig. 5).

\subsubsection{Silicate-only samples}

Olivine: The spectrum of unweathered Oll sample (Fig. 5A) shows the typical absorption band of Mg-rich olivine centered at $1.04 \mu \mathrm{m}$. A broad, shallow band cen- tered near $1.9 \mu \mathrm{m}$ also appears and is attributed to orthopyroxene. Spectra of $\mathrm{Oll}-\mathrm{H}_{2} \mathrm{O}$ and $\mathrm{O} 11-\mathrm{H}_{2} \mathrm{O}_{2}$ (weathered) samples show the same spectral features (Fig. 5B). The only differences observed are a small absorption at $1.91 \mu \mathrm{m}$ (more pronounced in $\mathrm{O} 11-\mathrm{H}_{2} \mathrm{O}_{2}$ ) and another one at $2.31 \mu \mathrm{m}$ (only in $\mathrm{Ol1}-\mathrm{H}_{2} \mathrm{O}$ ).

In the range $3.7-4.1 \mu \mathrm{m}$, where no absorption feature is observed for $\mathrm{Oll}$ and $\mathrm{O} 11-\mathrm{H}_{2} \mathrm{O}$, two bands located at 3.82 and $3.99 \mu \mathrm{m}$ appear in the spectrum of $\mathrm{Ol1}-\mathrm{H}_{2} \mathrm{O}_{2}$ (Fig. 5C). These bands are due to the presence of bicarbonate groups in the mineral structure (Calvin et al., 1994) and can thus be attributed to the neoformed nesquehonite. This is confirmed by the comparison with a natural, nesquehonite-rich sample of $\mathrm{Mg}$-carbonate (Fig. 5C). The two bands are also identified in $\mathrm{O} 12-\mathrm{H}_{2} \mathrm{O}$ and $\mathrm{O} 12-\mathrm{H}_{2} \mathrm{O}_{2}$ samples.

Clinopyroxene: The spectrum of unweathered $\mathrm{CPx}$ sample shows the typical absorption bands of clinopyroxene at 1.04 and $2.3 \mu \mathrm{m}$ (Fig. 5A). A very subtle hydration band is also observed at $1.91 \mu \mathrm{m}$. Spectra of $\mathrm{CPx}-\mathrm{H}_{2} \mathrm{O}$ and $\mathrm{CPx}-$ $\mathrm{H}_{2} \mathrm{O}_{2}$ samples are nearly identical to the one of the unweathered sample, except that the $1.91-\mu \mathrm{m}$ band is slightly more pronounced (Fig. 5B).

Orthopyroxene: The spectrum of unweathered OPx sample shows the typical absorption bands of orthopyroxene at 

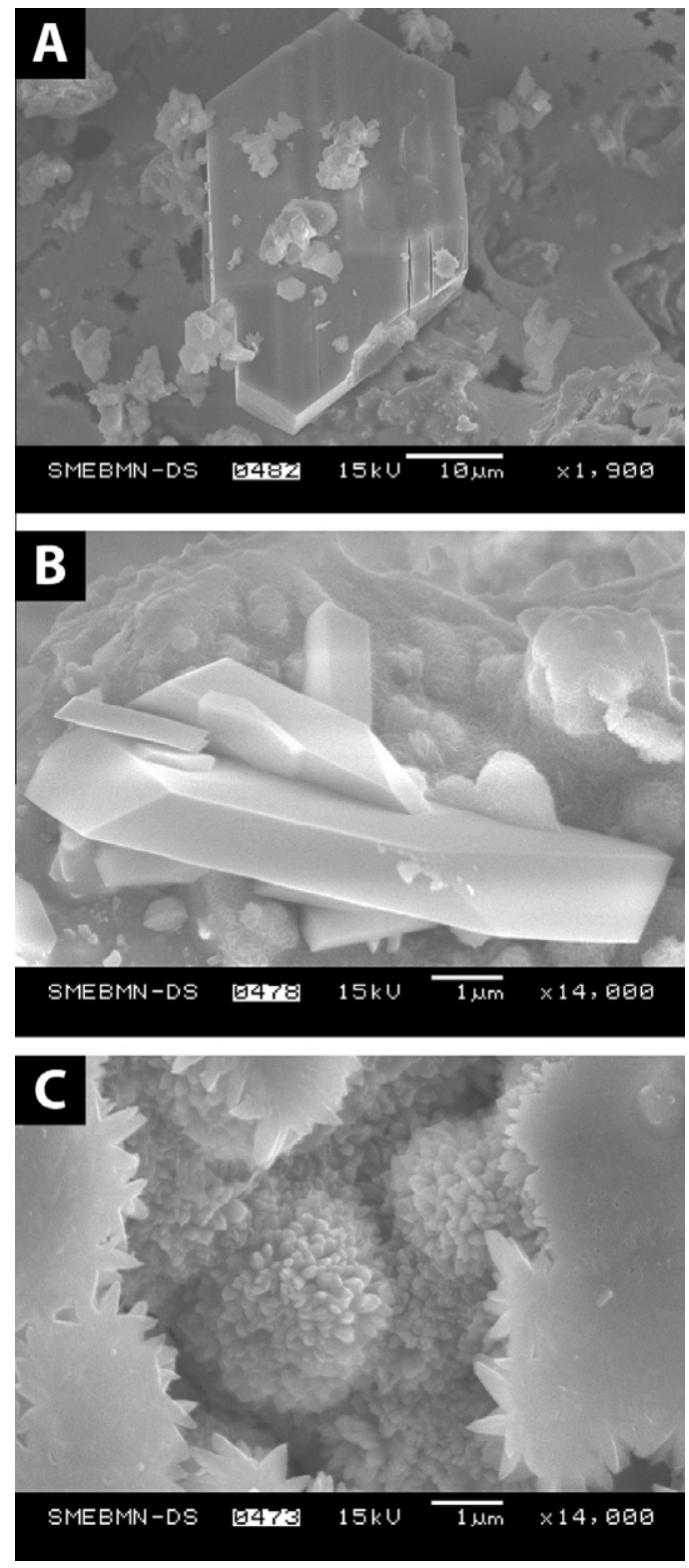

Fig. 4. Scanning electron microscope (SEM) images of secondary gypsum (A), jarosite (B) and goethite (C) produced during weathering in the $\mathrm{CPx}-\mathrm{HPo}-\mathrm{H}_{2} \mathrm{O}$ sample.

0.9 and $1.85 \mu \mathrm{m}$ (Fig. 5A). The spectrum of $\mathrm{OPx}-\mathrm{H}_{2} \mathrm{O}_{2}$ shows no difference compared to the unweathered OPx, whereas a small absorption band at $2.31 \mu \mathrm{m}$ is observed in the spectrum of $\mathrm{OPx}-\mathrm{H}_{2} \mathrm{O}$ (Fig. 5B).

\subsubsection{Silicate/sulfide mixtures}

Olivine + pyrrhotite: Pyrrhotite shows no absorption band in the range $1.0-2.5 \mu \mathrm{m}$ (Fig. 5D) but its reflectance is low. As a result, the spectral signature of olivine is strongly attenuated in the unweathered Ol1-HPo sample. However, the $1.04-\mu \mathrm{m}$ band of olivine remains clearly visible.

The spectra of Oll- $\mathrm{HPo}-\mathrm{H}_{2} \mathrm{O}$ and $\mathrm{Oll}-\mathrm{HPo}-\mathrm{H}_{2} \mathrm{O}_{2}$ (weathered) samples are very different from the unweath- ered one (Fig. 5E). The 1.04- $\mu \mathrm{m}$ band of olivine has shifted to shorter wavelengths, matching the signature of goethite (Fig. 5F). Moreover, several new bands appear at 1.45 , 1.94 and $2.4 \mu \mathrm{m}$. Both the 1.45- and $1.94-\mu \mathrm{m}$ bands are due to $\mathrm{H}_{2} \mathrm{O}$ molecules, whereas the $2.4-\mu \mathrm{m}$ band is due to $\mathrm{S}-\mathrm{O}$ chemical bonds, i.e. to $\mathrm{SO}_{4}$ groups (Cloutis et al., 2006). The new bands can thus be attributed to the hydrated sulfates detected by XRD (Fig. 5F). The greater band depths for the sample weathered in the $\mathrm{H}_{2} \mathrm{O}+\mathrm{H}_{2} \mathrm{O}_{2}$-bearing atmosphere are consistent with the higher quantities of sulfates determined by XRD.

Clinopyroxene + pyrrhotite: As for olivine, the spectral signature of diopside is attenuated by the mixture with pyrrhotite in the unweathered sample (Fig. 5D). The 1.04- $\mu \mathrm{m}$ band is still clearly visible, while the $2.3-\mu \mathrm{m}$ one has become subtle.

In the spectra of weathered samples, the $1.04-\mu \mathrm{m}$ band has shifted to shorter wavelengths, again matching the signature of goethite (Fig. 5F). New bands appear at the same position than previously $(1.45,1.94$ and $2.4 \mu \mathrm{m})$, again indicating the presence of hydrated sulfates. In addition, the spectrum of $\mathrm{CPx}-\mathrm{HPo}-\mathrm{H}_{2} \mathrm{O}_{2}$ sample shows a small absorption located at $2.27 \mu \mathrm{m}$, which can be attributed to jarosite (Fig. 5F; Cloutis et al., 2006).

Orthopyroxene + pyrrhotite: Despite the attenuation caused by pyrrhotite, the two typical bands of enstatite at 0.9 and $1.85 \mu \mathrm{m}$ are still clearly visible in the unweathered OPx-HPo sample (Fig. 5D).

For the weathered samples, it is difficult to know if the center of the $0.9 \mu \mathrm{m}$ band has shifted or not, since it is located outside the wavelength range of the FTIR both in initial orthopyroxene and in neoformed goethite. However, the band appears to be broader in the weathered samples compared with the unweathered one and is thus more compatible with goethite (Fig. 5F).

The spectrum of the $\mathrm{OPx}-\mathrm{HPo}-\mathrm{H}_{2} \mathrm{O}$ sample presents no detectable $1.45-\mu \mathrm{m}$ band and the bands at 1.94 and $2.4 \mu \mathrm{m}$ are quiet subtle (Fig. 5E). This is consistent with the limited alteration of this sample noticed in the XRD data. In contrast, the spectrum of the $\mathrm{OPx}-\mathrm{HPo}-\mathrm{H}_{2} \mathrm{O}_{2}$ sample shows clear absorption bands at $1.45,1.94$ and $2.4 \mu \mathrm{m}$. Finally, the broad $1.85-\mu \mathrm{m}$ band of enstatite has become very shallow in both weathered samples.

\subsubsection{Synthesis}

As expected, spectra of the samples without sulfide are very similar before and after weathering (Fig. 5A and B). However, for the three samples where nesquehonite is detected by XRD, small absorption bands appear in the corresponding spectra at $\sim 1.9$ and $\sim 3.8-3.9 \mu \mathrm{m}$ (Fig. 5B), consistent with $\mathrm{H}_{2} \mathrm{O}$ molecules and bicarbonate groups (Calvin et al., 1994) in the mineral structure, respectively. Comparison with a nesquehonite-rich natural sample also gives a good agreement (Fig. 5C). Mg-carbonates spectra usually display narrow bands at $\sim 2.3$ and $\sim 2.5 \mu \mathrm{m}$, but these bands are smaller than those beyond $3 \mu \mathrm{m}$, thus making them invisible given the proportion considered here. Nevertheless, a very subtle absorption band appeared at $2.3 \mu \mathrm{m}$ on the spectra of $\mathrm{Ol}-\mathrm{H}_{2} \mathrm{O}$ and $\mathrm{OPx}-\mathrm{H}_{2} \mathrm{O}$ samples that could be explained by carbonates. Alternatively, given 

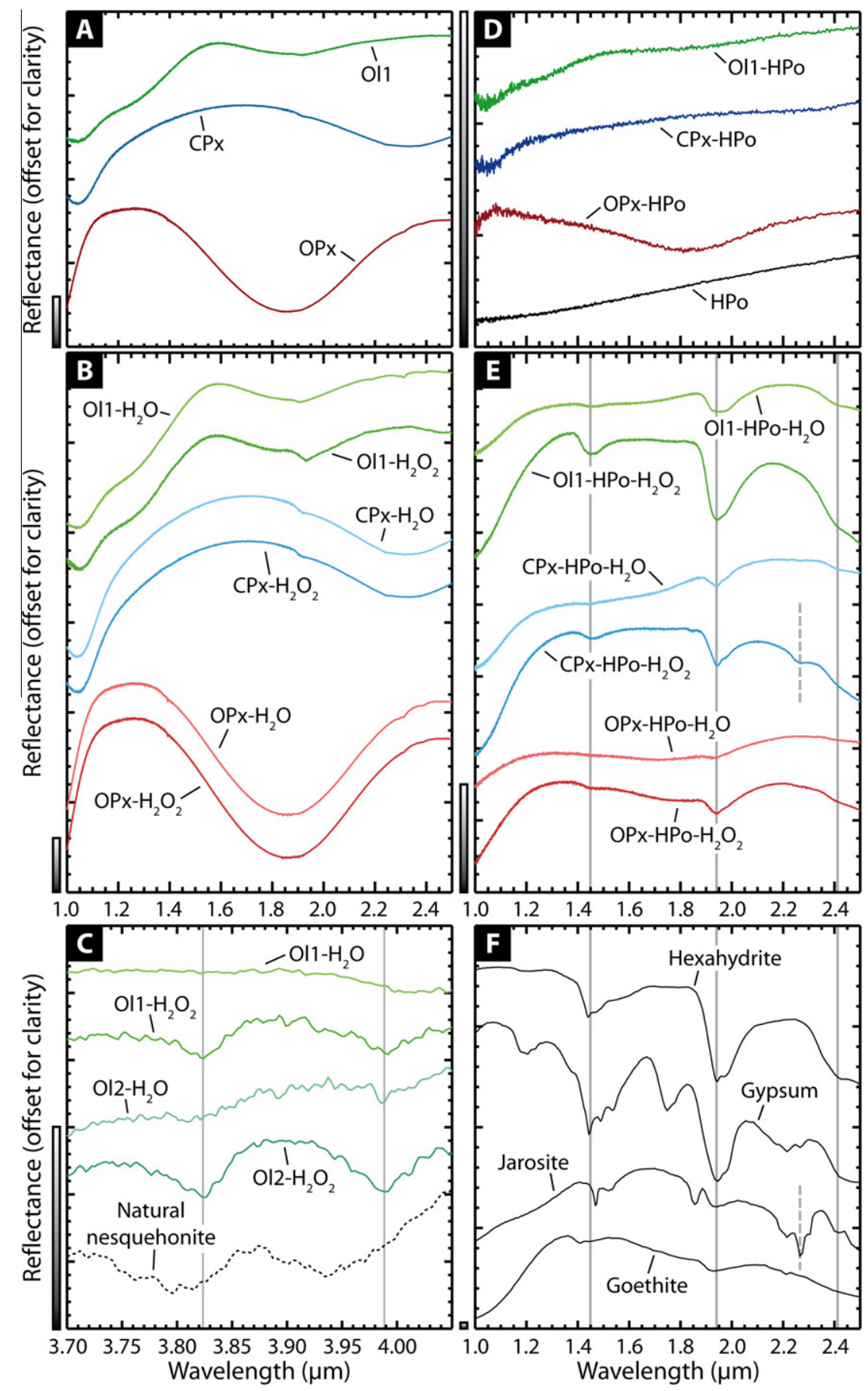

Fig. 5. Infrared spectra of initial and final samples of the experiment. Vertical bars are 3\% reflectance. (A) Silicate-only samples before weathering. (B) Silicate-only samples after weathering. (C) Spectra of olivine samples in the 4- $\mu \mathrm{m}$ region, displaying Mg-carbonate-related absorption bands (not detected in $\mathrm{Ol1}-\mathrm{H}_{2} \mathrm{O}$ ). A natural sample of nesquehonite shows a similar pattern with a slight shift in wavelength likely due to the presence of other species of Mg-carbonate (detected by XRD). (D) Silicate/sulfide mixtures before weathering and of pyrrhotite alone for comparison. (E) Silicate/sulfide mixtures after weathering. (F) Laboratory spectra of hexahydrite ${ }^{\mathrm{a}}$, jarosite ${ }^{\mathrm{b}}$, gypsum ${ }^{\mathrm{b}}$ and goethite $^{\mathrm{b}}$. ${ }^{\mathrm{a}}$ RELAB library \#LASF57A; data and sample description available at http://psf.uwinnipeg.ca/Sample_Database.html. ${ }^{\mathrm{b}}$ USGS library \#GDS99, \#HS333.3B and \#WS219 (Clark et al., 2007).

the lack of associated $2.5-\mu \mathrm{m}$ band, this signature may correspond to another $\mathrm{Mg}-\mathrm{OH}$-bearing secondary phase, such as a precursor of $\mathrm{Mg}$-phyllosilicates. However, the very small amount involved prevents any definitive identification with the analytical techniques available to us.
Spectra of silicate/sulfide mixtures show more extensive modifications (Fig. 5D and E). The spectral signature of silicates, that is still detectable in the unaltered $50 \mathrm{wt} . \%$ mixtures with pyrrhotite, had nearly completely disappeared after weathering despite the high quantity of 
remaining silicates ( $>30$ vol \%, Table 2$)$. Instead, absorption features of goethite (at $0.93 \mu \mathrm{m}$ ) and hydrated sulfates (at $1.45,1.94$ and $2.4 \mu \mathrm{m}$ ) became dominant. Another absorption feature located at $2.27 \mu \mathrm{m}$ is observed in the spectrum of $\mathrm{CPx}-\mathrm{HPo}-\mathrm{H}_{2} \mathrm{O}_{2}$ sample and can be attributed to jarosite (Fig. 5F), consistent with the XRD results. However, apart from this last case, the near-infrared spectra alone are not sufficient to identify the exact sulfate species which formed. For example, the typical absorption features of gypsum at 1.20, 1.75 and 2.21$2.28 \mu \mathrm{m}$ are never observed (Fig. 5F), despite the amount of gypsum being $\sim 10 \mathrm{vol} \%$ in some samples. This is probably an effect of grain size, because crystals of gypsum are large but scattered, whereas those of goethite are small but widespread, as shown by SEM observations (Fig. 4). As a result, the goethite must cover a greater portion of the surface of the powder and hence its spectral signature must prevail over the gypsum one.

\section{DISCUSSION}

\subsection{Weathering processes without sulfide}

In the absence of sulfide, the weathering of silicates is not efficient. This was expected, as several previous experimental studies have shown that the direct effect of $\mathrm{CO}_{2}$ on weathering rates of mafic minerals is very weak (the main controlling parameters are temperature and $\mathrm{pH}$; Golubev et al., 2005). Only olivine, which is less resistant to alteration than pyroxenes (e.g., Brady and Walther, 1989; Franke and Teschner-Steinhardt, 1994), developed a secondary phase, namely the Mg-carbonate nesquehonite:

$$
\begin{aligned}
& \frac{1}{2} \mathrm{Mg}_{2} \mathrm{SiO}_{4}+\mathrm{CO}_{2}+3 \mathrm{H}_{2} \mathrm{O} \\
& \quad=\mathrm{Mg}\left(\mathrm{HCO}_{3}\right)(\mathrm{OH}) \cdot 2 \mathrm{H}_{2} \mathrm{O}+\frac{1}{2} \mathrm{SiO}_{2} \\
& \frac{1}{2} \mathrm{Mg}_{2} \mathrm{SiO}_{4}+\mathrm{CO}_{2}+3 \mathrm{H}_{2} \mathrm{O}_{2} \\
& \quad=\mathrm{Mg}\left(\mathrm{HCO}_{3}\right)(\mathrm{OH}) \cdot 2 \mathrm{H}_{2} \mathrm{O}+\frac{1}{2} \mathrm{SiO}_{2}+\frac{3}{2} \mathrm{O}_{2}
\end{aligned}
$$

In natural environments on Earth, nesquehonite tends to transform into more stable magnesite $\mathrm{MgCO}_{3}$ (Fallick et al., 1991) via progressive dehydration and resulting intermediate phases, which include hydromagnesite $\left(\mathrm{MgCO}_{3}\right)_{4} \cdot \mathrm{Mg}(\mathrm{OH})_{2} \cdot 4 \mathrm{H}_{2} \mathrm{O}$ (Davies and Bubela, 1973; Hänchen et al., 2008). On Mars, the few carbonate-bearing outcrops discovered so far are uniquely associated with olivinebearing units and are composed of mainly magnesite and hydromagnesite (Ehlmann et al., 2008; Morris et al., 2010). Our results show that these outcrops could derive from weathering of olivine-bearing rocks under a $\mathrm{CO}_{2}$ dominated atmosphere with both total pressure and partial pressure of $\mathrm{H}_{2} \mathrm{O}$ high enough to allow liquid water to condensate at the surface of the grains. Such weathering could have led to the release of $\mathrm{H}_{2}$ and $\mathrm{CH}_{4}$ in the atmosphere, even at low temperature (Neubeck et al., 2011), but this process was not observable in our data. In contrast, the formation of Ca-carbonates from Ca-bearing silicates (e.g., diopside) could have been partially precluded by slower reaction rates on Mars, as it may have been in our experiment (Franke and Teschner-Steinhardt, 1994). Lastly, our experimental conditions could have favored the formation of phyllosilicates, but this was likely precluded by slow reaction rates, too.

\subsection{Weathering processes with sulfide}

The weathering of silicate/sulfide mixtures produced complex parageneses, composed of unaltered silicates, traces of remaining pyrrhotite, elemental sulfur, hydrated sulfates and Fe-(oxy)hydroxides (Table 2). Elemental sulfur and $\mathrm{Fe}-(\mathrm{oxy})$ hydroxides are direct products of pyrrhotite, as previously observed by Chevrier et al. (2004):

$$
\begin{aligned}
\mathrm{Fe}_{(1-x)} \mathrm{S}+(2-2 x) \mathrm{H}_{2} \mathrm{O}= & (1-x) \mathrm{FeO}(\mathrm{OH})+\mathrm{S}^{0} \\
& +\frac{(3-3 x)}{2} \mathrm{H}_{2} \\
\mathrm{Fe}_{(1-x)} \mathrm{S}+(1-x) \mathrm{H}_{2} \mathrm{O}_{2}= & (1-x) \mathrm{FeO}(\mathrm{OH})+\mathrm{S}^{0} \\
& +\frac{(1-x)}{2} \mathrm{H}_{2}
\end{aligned}
$$

In contrast, the production of sulfates is a two-step process involving both the production of sulfuric acid by further oxidation of sulfur and the dissolution of the silicate. Here is an example for hexahydrite production from olivine/pyrrhotite mixtures:

$$
\begin{aligned}
& \mathrm{S}^{0}+4 \mathrm{H}_{2} \mathrm{O}=\mathrm{H}_{2} \mathrm{SO}_{4}+3 \mathrm{H}_{2} \\
& \mathrm{~S}^{0}+2 \mathrm{H}_{2} \mathrm{O}_{2}=\mathrm{H}_{2} \mathrm{SO}_{4}+\mathrm{H}_{2} \\
& \frac{1}{2} \mathrm{Mg}_{2} \mathrm{SiO}_{4}+2 \mathrm{H}^{+}+\mathrm{SO}_{4}{ }^{2-}+5 \mathrm{H}_{2} \mathrm{O} \\
& \quad=\mathrm{MgSO}_{4} \cdot 6 \mathrm{H}_{2} \mathrm{O}+\frac{1}{2} \mathrm{SiO}_{2}
\end{aligned}
$$

Excess of $\mathrm{Fe}$ and $\mathrm{S}$ released by pyrrhotite can also combine to form jarosite through the following reaction (given here for hydronium-jarosite, but K- or Na-jarosite can also appear since $\mathrm{K}$ and $\mathrm{Na}$ are present in the system; see Table 1):

$$
3 \mathrm{Fe}^{3+}+2 \mathrm{SO}_{4}{ }^{2-}+7 \mathrm{H}_{2} \mathrm{O}=\left(\mathrm{H}_{3} \mathrm{O}\right) \mathrm{Fe}_{3}\left(\mathrm{SO}_{4}\right)_{2}(\mathrm{OH})_{6}+5 \mathrm{H}^{+}
$$

The presence of jarosite in three pyroxene/pyrrhotite mixtures shows that the weathering of pyrrhotite caused severe acidification, since jarosite is only stable at $\mathrm{pH}<4$ (Bigham et al., 1996; Elwood Madden et al., 2004). A possible explanation for its absence in the olivine/pyrrhotite mixtures is that the release of basic $\mathrm{Mg}^{2+}$ cations by olivine caused a buffering effect in these samples, resulting in a higher $\mathrm{pH}$ than in the pyroxene/pyrrhotite mixtures. The formation of $\mathrm{Ca}$ - and $\mathrm{Mg}$-sulfates demonstrates that silicates were altered along with pyrrhotite, because silicates were the only source of these cations in our closed chemical system (Eq. (4)). Therefore, the acidification induced by the weathering of pyrrhotite appears to promote the weathering of silicates (Sherlock et al., 1995). This process is expected to generate a Si-rich residue (Eq. (4); Tosca et al., 2004; Golden et al., 2005) and, indeed, some areas enriched 
in $\mathrm{Si}$ whereas impoverished in other cations were found by SEM (Fig. 6). Since no Si-bearing phases other than the initial silicates were detected by XRD, this residue must be poorly crystallized or amorphous (Golden et al., 2005). Thus, we interpret the Si-rich phase observed by SEM to be amorphous silica. XRD also indicates that this phase must be quite minor in the bulk sample, unless it would have been visible in the diffraction patterns as a broad hump at $2 \theta \approx 20-40^{\circ}$.

Hydrated sulfates and Fe-(oxy)hydroxides closely match some mineralogical assemblages observed in Meridiani Planum (Christensen et al., 2004; Klingelhöfer et al., 2004) and Valles Marineris (Mangold et al., 2008; Wendt et al., 2010), especially since goethite is known to evolve to hematite under heating or decreasing water vapor activity (Gooding, 1978). Furthermore, the near-infrared spectra obtained from our samples show a very good agreement with some data acquired in these regions by spaceborne imaging spectrometers: the absorption features at $1.0-1.3 \mu \mathrm{m}, \sim 1.9$ and $\sim 2.4 \mu \mathrm{m}$ are correctly reproduced (Fig. 7). Comparison with our results suggests that Martian formations that are found to be rich in sulfates and/or Fe-(oxy)hydroxides could also contain a significant unaltered basaltic component, which is not seen in the spectra. The detection of such component in the Burns formation by both thermal infrared remote-sensing (Christensen et al., 2001) and in situ observations (Clark et al., 2005; Morris et al., 2006) supports this interpretation.

Since our results have been obtained with a high proportion of sulfides in the initial samples (see Section 3.1.2), it is necessary to consider the possible differences that could have been observed with a more common sulfide content $(<1 \%$; Lorand et al., 2005; King and McLennan, 2010). First, the coexistence in our final samples of sulfates and non-oxidized pyrrhotite is probably the consequence of the high proportion of pyrrhotite in the initial samples (and also of the inevitably-limited duration of the experiment). With less pyrrhotite at the start (or more time), pyrrhotite and then elemental sulfur would have been expected to disappear completely by progressive oxidation (Eqs. (2) and (3); see also Section 5.3). Second, the sulfates formed would have been mechanically less abundant with lower sulfide content, due to the lower availability of $\mathrm{SO}_{4}{ }^{2-}$ (Eqs. (2) and (3)). However, given the low water-to-rock ratio and the absence of any stirring or mixing system in our experimental apparatus, the same chemical and mineralogical processes would have been expected to happen at the grain scale (McHenry et al., 2011), and so the same secondary phases would have been expected to form. The possible ways to concentrate sulfates at the same levels than those observed in Meridiani Planum or elsewhere on Mars will be discussed in Section 6.

\subsection{Source of oxidation and role of $\mathrm{H}_{2} \mathrm{O}_{2}$}

The precipitation of sulfates and Fe-(oxy)hydroxides requires an oxidizing environment. Thermodynamic calculations have shown that Fe-sulfides could be oxidized by water equilibrated with atmospheric oxygen even
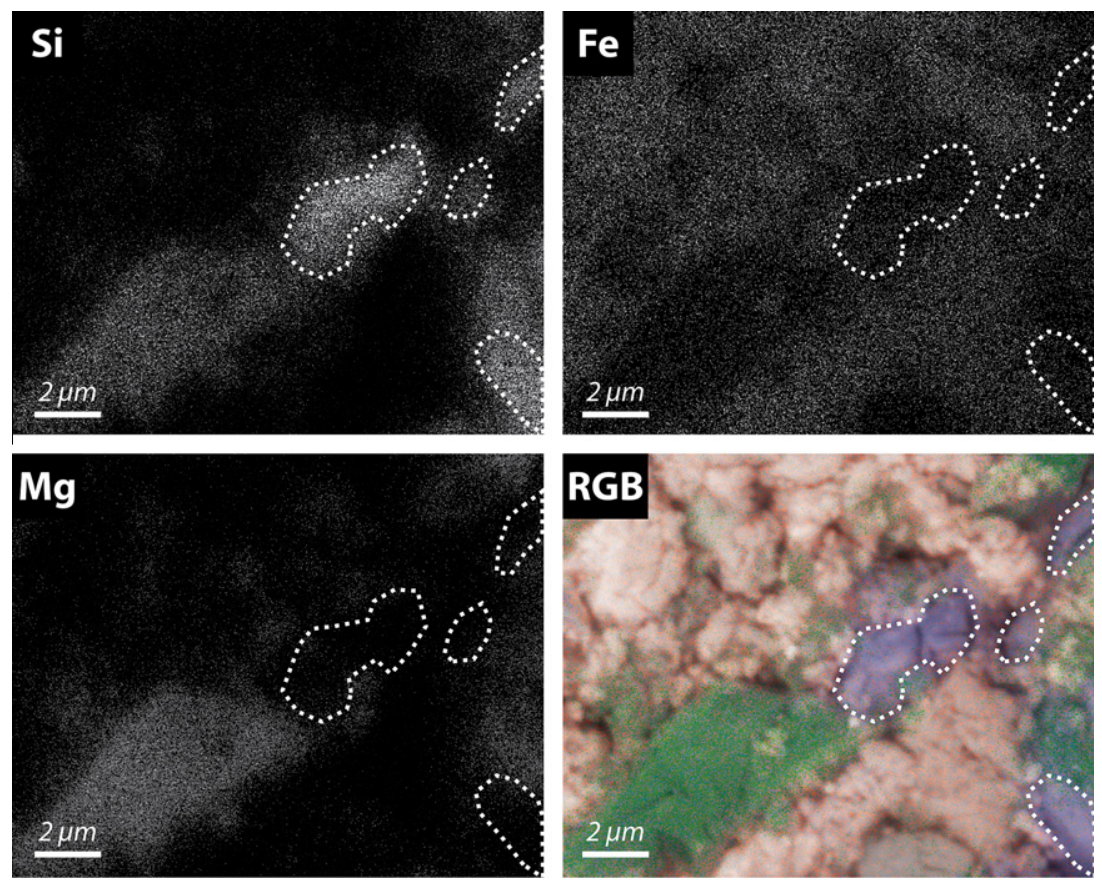

Fig. 6. SEM mapping of $\mathrm{Si}, \mathrm{Mg}$ and $\mathrm{Fe}$ in a portion of the $\mathrm{Ol1}-\mathrm{HPo}-\mathrm{H}_{2} \mathrm{O}_{2}$ sample. Dotted lines indicate areas enriched in $\mathrm{Si}$ and impoverished in $\mathrm{Mg}$ and $\mathrm{Fe}$ (other mapped elements for which data are not shown were also absent). The color image is a SEM photograph with the three elemental maps overlain on it (red: Fe; green: $\mathrm{Mg}$; blue: $\mathrm{Si}$ ). We interpret red areas to be iron (oxy)hydroxides, green areas to be olivine and blue areas to be amorphous silica. (For interpretation of the references to color in this figure legend, the reader is referred to the web version of this article.) 


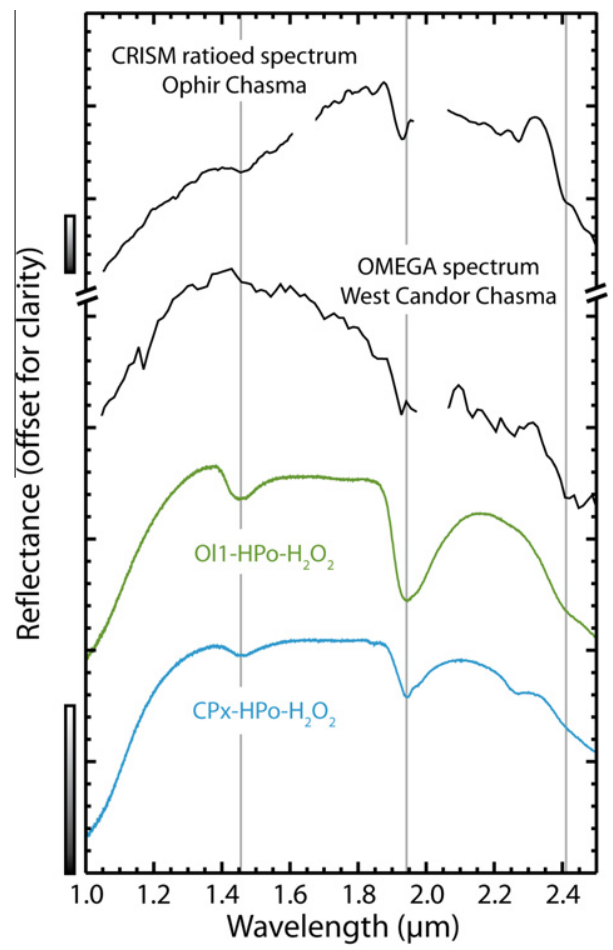

Fig. 7. Comparison between infrared spectra of sulfate- and Feoxide-bearing deposits on Mars and our experimentally weathered samples. From top to bottom: CRISM (Compact Reconnaissance Imaging Spectrometer for Mars) ratioed spectrum in Ophir Chasma (Wendt et al., 2010); OMEGA (Observatoire pour la Minéralogie, l'Eau, les Glaces et l'Activité) spectrum in West Candor Chasma (Mangold et al., 2008); Ol1- $\mathrm{HPo}-\mathrm{H}_{2} \mathrm{O}_{2}$ sample; $\mathrm{CPx}-\mathrm{HPo}-\mathrm{H}_{2} \mathrm{O}_{2}$ sample. Vertical bars are $3 \%$ reflectance.

under the very low oxygen partial pressure of the presentday Martian atmosphere (Burns and Fisher, 1990a; Zolotov and Shock, 2005). The amount of oxygen available for weathering could also be slightly increased through photochemical decomposition of $\mathrm{H}_{2} \mathrm{O}$ molecules followed by the escape of $\mathrm{H}_{2}$ into space (Lammer et al., 2003). However, our results clearly demonstrate that the formation of sulfates on Mars could have occurred under a $\mathrm{CO}_{2}$-rich atmosphere similar to today's, but with a higher $\mathrm{H}_{2} \mathrm{O}$ content. High partial pressures of $\mathrm{O}_{2}$ or $\mathrm{SO}_{2}$ (i.e., higher than today) are not required. The presence of $\mathrm{H}_{2} \mathrm{O}_{2}$ is not required either, since mineralogical assemblages are similar in our two types of atmosphere. However, the higher oxidizing power of $\mathrm{H}_{2} \mathrm{O}_{2}$ allows higher production of $\mathrm{H}_{2} \mathrm{SO}_{4}$, resulting in higher release of protons and $\mathrm{SO}_{4}{ }^{2-}$ anions in the medium (Fig. 8). Such conditions favor the precipitation of sulfates - and particularly jarosite - at the expense of elemental sulfur (which is always less abundant under $\mathrm{H}_{2} \mathrm{O}_{2}$-bearing atmosphere, as shown by Fig. 2). With lower $\mathrm{H}_{2} \mathrm{O}_{2}$-to- $\mathrm{H}_{2} \mathrm{O}$ ratios in natural systems (Liang et al., 2006), this effect is expected to be weaker than in our experiment, unless $\mathrm{H}_{2} \mathrm{O}_{2}$ is available continuously on very long timescales, which seems to have been the case for Mars (Bullock et al., 1994; Zent, 1998).

\section{IMPLICATIONS FOR SULFATES AND CARBONATES ON MARS}

Our results demonstrate that the combined alteration of silicates and sulfides under a $\mathrm{CO}_{2}$ atmosphere provides a viable geochemical model to explain the mineralogical complexity of the sulfate-bearing deposits observed on Mars. They are in good agreement with those of Zolotov and Shock (2005), obtained by a numerical approach. The progressive oxidation of sulfides allows the $\mathrm{pH}$ to be maintained in the small interval where jarosite and goethite are stable together (Zolotov and Shock, 2005) and promotes the alteration of silicates, allowing release of $\mathrm{Ca}$ and $\mathrm{Mg}$ cations which can be subsequently incorporated into $\mathrm{Ca}$ and $\mathrm{Mg}$-sulfates. Moreover, the coexistence of $\mathrm{Fe}$ and $\mathrm{S}$ inside Fe-sulfides makes the precipitation of jarosite easier than in a model involving only $\mathrm{Fe}^{2+}$ oxidation (Hurowitz et al., 2010), because $\mathrm{Fe}$ is immediately available at the grain scale after oxidation of $\mathrm{S}^{2-}$ into $\mathrm{SO}_{4}{ }^{2-}$ (McHenry et al., 2011). However, the two models could point toward similar implications, since the $\mathrm{S}$ content in magmas is correlated with their $\mathrm{Fe}$ content (Carroll and Rutherford, 1985; Gaillard and Scaillet, 2009). The weathering processes involving both silicates and sulfides are well known on Earth (Bladh, 1982; Sherlock et al., 1995; Moncur et al., 2009) and now appear to be relevant to Martian-like conditions, too.

Our results also show that carbonates could have appeared from a bedrock devoid of sulfides under the same atmosphere than sulfates (Fig. 8). Indeed, in our experiment, the presence of sulfuric acid in some sample-bearing cups did not prevent the precipitation of carbonates in some other cups. This could resolve the apparent paradox arising from the possible coeval formation of the two types of minerals (Ehlmann et al., 2008).

A potential issue of the "sulfide model" is how to explain the high sulfate content of the Burns formation, estimated to be $\sim 35-40 \mathrm{wt} . \%$ (McLennan et al., 2005). Simple mass balance calculations indicate that such abundance would require that the parent basaltic rock contains about $\sim 15$ wt. $\%$ pyrrhotite (or $\sim 12.5 \%$ pyrrhotite + pyrite), a value which is not realistic when compared to sulfide content of shergottites ( $\sim 0.5$ wt.\%; Lorand et al., 2005). However, SNC meteorites were probably ejected from Mars by only one or a few impacts (Vickery and Melosh, 1987; McSween, 1994), therefore not being necessarily representative of the widespread volcanic episodes of the Hesperian period. Indeed, segregation of S-rich liquid inside magma chambers can lead to the formation of massive sulfide deposits (with sulfide content from $20 \%$ to $90 \%$; Naldrett, 2004), a process observed on Earth in komatiitic context (Lesher et al., 1981). Sulfide-rich deposits can also be formed by precipitation from $\mathrm{H}_{2} \mathrm{~S}$-bearing waters in hydrothermal contexts (e.g., Robigou et al., 1993). The fact that Martian sulfates are strongly distributed in an equatorial band in the Tharsis bulge and west of it is in agreement with a high sulfur content of Tharsis magmas (up to $3500 \mathrm{ppm}$ of $\mathrm{S}$ in the case of a water-poor melt; Gaillard and Scaillet, 2009). Given the neutral signature of sulfides in infrared data (Fig. 5D) and the strongly oxidizing conditions of the Martian 


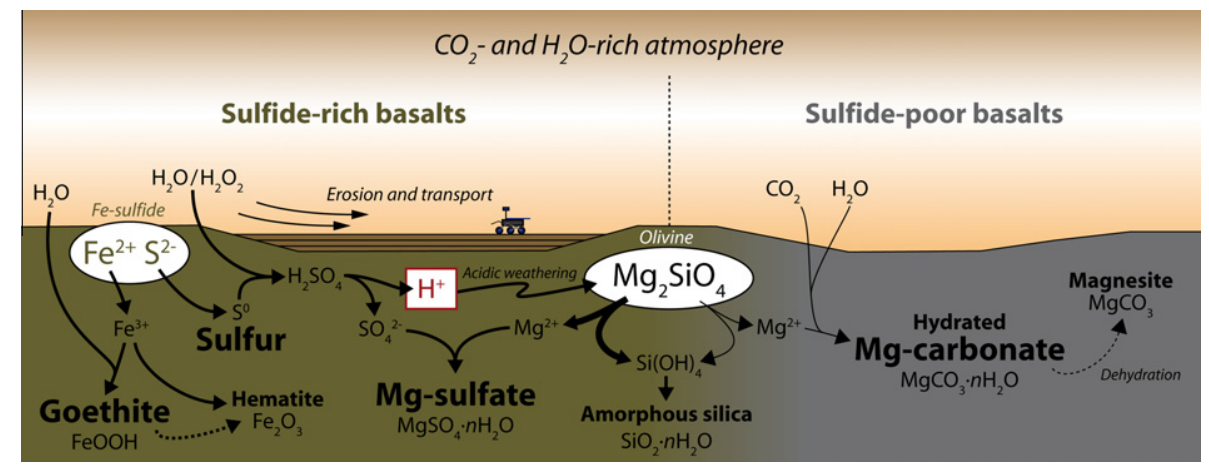

Fig. 8. Production of either sulfates or carbonates depending of the sulfide-content of the bedrock: example for Mg-olivine. Reactions are drawn in the ground for clarity; however they are valid both at the surface and in the shallow subsurface, where the porosity allows water and/ or hydrogen peroxide to be in contact with the minerals.

surface (Bullock et al., 1994; Zent, 1998), it is likely that potential sulfide-rich deposits could not be detected on Mars using orbital data.

Alternatively, sulfides or sulfates could have been accumulated by post-magmatic processes, such as aeolian segregation. Indeed, the discovery by the Opportunity rover of sedimentary lithologies, including layered and cross-bedded structures (Grotzinger et al., 2005), consistently implies that the weathering of the sulfide-bearing parent rocks occurred between or during episodes of erosion and transport. Observation of gypsum-rich ( $\sim 35$ wt. \%; Fishbaugh et al., 2007) sand dunes near the Martian polar cap (which have been proposed to derive from sulfide weathering; Fishbaugh et al., 2007; Szynkiewicz et al., 2010) suggests that sulfates may be little mobile during aeolian transport (gypsum concentration rapidly decreases in the direction of main winds), i.e., less mobile than other components. Thus, the long-term action of aeolian transport may increase the relative abundance of sulfates in sedimentary deposits compared to their parent rocks. Finally, the strong spectral signature of sulfates observed in some thick layered deposits within the Valles Marineris chasmata $(>4 \mathrm{~km}$ in West Candor Chasma; Mangold et al., 2008) may also be better explained if aeolian segregation was involved rather than in-place weathering only.

\section{CONCLUSIONS}

The present study provides the first experimental data about the impact of Fe-sulfides on the weathering of basaltic silicates under simulated early-Martian conditions. We have shown that even in the nearly-absence of $\mathrm{O}_{2}$ the weathering of sulfides causes severe acidification of the surrounding medium and by this way promotes the weathering of silicates and the precipitation of secondary phases dominated by hydrated sulfates and Fe-(oxy)hydroxides (elemental sulfur is also produced but tends to decrease with time; Fig. 8). Both final mineralogy and near-infrared spectra give a good agreement with spaceborne and in situ observations of the Martian sulfate- and Fe-oxide-bearing terrains. Therefore, our experimental results strongly support the idea that sulfides have played a major role in the formation of sulfates on Mars (Burns, 1987). They show that regional bedrock enrichment in sulfides is sufficient to explain the formation of sulfates locally and that no global acidic event is required. This explains the preservation of carbonates and phyllosilicates that otherwise would have been destroyed by such a late global acidic environment (Fairen et al., 2004; Altheide et al., 2010). This result is positive concerning the search of ancient life on Mars (Navarro-Gonzalez et al., 2010; Bishop et al., 2011), because it suggests that early sediments could have been preserved from acidic weathering in regions with initial low sulfide content.

\section{ACKNOWLEDGMENTS}

The authors thank three anonymous reviewers and the associate editor Roy Wogelius for their revisions which greatly improved the quality of the manuscript. The authors thank the Muséum National d'Histoire Naturelle of Paris (especially Dr. Cristiano Ferraris and Pr. François Farges) which provided the Ol1, CPx and OPx samples, as well as the nesquehonite-bearing sample. The authors also thank Daniel Borschneck (CEREGE, Aix-en-Provence), Pierre-Emmanuel Petit, Nicolas Stéphant and Stéphane Grolleau (IMN, Nantes) for their technical assistance. This work was supported by the French Programme National de Planétologie (PNP) of the Institut National des Sciences de l'Univers (INSU) and by the Centre National d'Études Spatiales (CNES).

\section{APPENDIX A. SUPPLEMENTARY DATA}

Supplementary data associated with this article can be found, in the online version, at http://dx.doi.org/10.1016/ j.gca.2012.04.057.

\section{REFERENCES}

Altheide T. S., Chevrier V. and Noe Dobrea E. (2010) Mineralogical characterization of acid weathered phyllosilicates with implications for secondary martian deposits. Geochim. Cosmochim. Acta 74, 6232-6248.

Bates D. R. and Nicolet M. (1950) The photochemistry of atmospheric water vapor. J. Geophys. Res. 55, 301-327.

Berger G., Toplis M. J., Treguier E., d'Uston C. and Pinet P. (2009) Evidence in favor of small amounts of ephemeral and transient 
water during alteration at Meridiani Planum, Mars. Am. Mineral. 94, 1279-1282.

Bibring J. P., Langevin Y., Gendrin A., Gondet B., Poulet F., Berthe M., Soufflot A., Arvidson R., Mangold N., Mustard J. and Drossart P. (2005) Mars surface diversity as revealed by the OMEGA/Mars Express observations. Science 307, 1576-1581.

Bibring J. P., Langevin Y., Mustard J. F., Poulet F., Arvidson R., Gendrin A., Gondet B., Mangold N., Pinet P. and Forget F. (2006) Global mineralogical and aqueous Mars history derived from OMEGA/Mars express data. Science 312, 400-404.

Bigham J. M., Schwertmann U., Traina S. J., Winland R. L. and Wolf M. (1996) Schwertmannite and the chemical modeling of iron in acid sulfate waters. Geochim. Cosmochim. Acta 60, 2111-2121.

Bishop J. L., Schelble R. T., McKay C. P., Brown A. J. and Perry K. A. (2011) Carbonate rocks in the Mojave Desert as an analogue for Martian carbonates. Int. J. Astrobiol. 10, 349-358.

Bladh K. W. (1982) The formation of goethite, jarosite, and alunite during the weathering of sulfide-bearing felsic rocks. Econ. Geol. 77, 176-184.

Boynton W. V., Ming D. W., Kounaves S. P., Young S. M. M., Arvidson R. E., Hecht M. H., Hoffman J., Niles P. B., Hamara D. K., Quinn R. C., Smith P. H., Sutter B., Catling D. C. and Morris R. V. (2009) Evidence for calcium carbonate at the Mars Phoenix landing site. Science 325, 61-64.

Brady P. V. and Walther J. V. (1989) Controls on silicate dissolution rates in neutral and basic $\mathrm{pH}$ solutions at $25^{\circ} \mathrm{C}$. Geochim. Cosmochim. Acta 53, 2823-2830.

Brown A. J., Hook S. J., Baldridge A. M., Crowley J. K., Bridges N. T., Thomson B. J., Marion G. M., de Souza C. R. and Bishop J. L. (2010) Hydrothermal formation of clay-carbonate alteration assemblages in the Nil Fossae region of Mars. Earth Planet. Sci. Lett. 297, 174-182.

Bullock M. A., Stoker C. R., McKay C. P. and Zent A. P. (1994) A coupled soil-atmosphere model of $\mathrm{H}_{2} \mathrm{O}_{2}$ on Mars. Icarus 107, $142-154$.

Bullock M. A., Moore J. M. and Mellon M. T. (2004) Laboratory simulations of Mars aqueous geochemistry. Icarus 170, 404 423.

Burns R. G. (1987) Ferric sulfates on Mars. J. Geophys. Res. 92, E570-E574.

Burns R. G. and Fisher D. S. (1990a) Evolution of sulfide mineralization on Mars. J. Geophys. Res. 95, 14169-14173.

Burns R. G. and Fisher D. S. (1990b) Iron-sulfur mineralogy of Mars: magmatic evolution and chemical weathering products. J. Geophys. Res. 95, 14415-14421.

Calvin W. M., King T. V. V. and Clark R. N. (1994) Hydrous carbonates on Mars? Evidence from Mariner 6/7 infrared spectrometer and ground-based telescopic spectra. J. Geophys. Res. 99, 14659-14675.

Carpenter R. H. (1974) Pyrrhotite isograd in southeastern Tennessee and southwestern North Carolina. Geol. Soc. Am. Bull. 85, 451-456.

Carr M. H. and Head J. W. (2010) Geologic history of Mars. Earth Planet. Sci. Lett. 294, 185-203.

Carroll M. R. and Rutherford M. J. (1985) Sulfide and sulfate saturation in hydrous silicate melts. J. Geophys. Res. $\mathbf{9 0}$ (Suppl.), C601-C612.

Chevrier V. and Mathé P. E. (2007) Mineralogy and evolution of the surface of Mars: a review. Planet. Space Sci. 55, 289-314.

Chevrier V., Rochette P., Mathe P. E. and Grauby O. (2004) Weathering of iron-rich phases in simulated Martian atmospheres. Geology 32, 1033-1036.

Chevrier V., Mathé P. E., Rochette P., Grauby O., Bourrie G. and Trolard F. (2006) Iron weathering products in a $\mathrm{CO}_{2}+\left(\mathrm{H}_{2} \mathrm{O}\right.$ or
$\mathrm{H}_{2} \mathrm{O}_{2}$ ) atmosphere: implications for weathering processes on the surface of Mars. Geochim. Cosmochim. Acta 70, 4295-4317.

Christensen P. R., Morris R. V., Lane M. D., Bandfield J. L. and Malin M. C. (2001) Global mapping of Martian hematite mineral deposits: remnants of water-driven processes on early Mars. J. Geophys. Res. Planets 106, 23873-23885.

Christensen P. R., Wyatt M. B., Glotch T. D., Rogers A. D., Anwar S., Arvidson R. E., Bandfield J. L., Blaney D. L., Budney C., Calvin W. M., Faracaro A., Fergason R. L., Gorelick N., Graff T. G., Hamilton V. E., Hayes A. G., Johnson J. R., Knudson A. T., McSween H. Y., Mehall G. L., Mehall L. K., Moersch J. E., Morris R. V., Smith M. D., Squyres S. W., Ruff S. W. and Wolff M. J. (2004) Mineralogy at Meridiani Planum from the Mini-TES experiment on the Opportunity Rover. Science 306, 1733-1739.

Clancy R. T., Sandor B. J. and Moriarty-Schieven G. H. (2004) A measurement of the $362 \mathrm{GHz}$ absorption line of Mars atmospheric $\mathrm{H}_{2} \mathrm{O}_{2}$. Icarus $\mathbf{1 6 8}, 116-121$.

Clark B. C., Morris R. V., McLennan S. M., Gellert R., Jolliff B., Knoll A. H., Squyres S. W., Lowenstein T. K., Ming D. W., Tosca N. J., Yen A., Christensen P. R., Gorevan S., Bruckner J., Calvin W., Dreibus G., Farrand W., Klingelhoefer G., Waenke H., Zipfel J., Bell J. F., Grotzinger J., McSween H. Y. and Rieder R. (2005) Chemistry and mineralogy of outcrops at Meridiani Planum. Earth Planet. Sci. Lett. 240, 73-94.

Clark R. N., Swayze G. A., Wise R., Livo E., Hoefen T., Kokaly R. and Sutley S. J. (2007) USGS digital spectral library splib06a, U.S. Geological Survey Digital Data Series 231. Available from: $<$ http://speclab.cr.usgs.gov/spectral.lib06>.

Cloutis E. A., Hawthorne F. C., Mertzman S. A., Krenn K., Craig M. A., Marcino D., Methot M., Strong J., Mustard J. F., Blaney D. L., Bell J. F. and Vilas F. (2006) Detection and discrimination of sulfate minerals using reflectance spectroscopy. Icarus 184, 121-157.

Cullity B. D. (1956) Elements of X-ray Diffraction. Addison-Wesley Publishing Company Inc., Reading, Massachusetts.

Davies P. J. and Bubela B. (1973) Transformation of nesquehonite into hydromagnesite. Chem. Geol. 12, 289-300.

de Moor J. M., King P. L., Sharp Z. D. and Fischer T. P. (2011) A model for sulfur speciation and sulfur isotope fractionation during magmatic degassing on Earth and Mars. Lunar Planet. Sci. Conf. XLII, \#1238 (abstr.).

Ehlmann B. L., Mustard J. F., Murchie S. L., Poulet F., Bishop J. L., Brown A. J., Calvin W. M., Clark R. N., Des Marais D. J., Milliken R. E., Roach L. H., Roush T. L., Swayze G. A. and Wray J. J. (2008) Orbital identification of carbonate-bearing rocks on Mars. Science 322, 1828-1832.

Elwood Madden M. E., Bodnar R. J. and Rimstidt J. D. (2004) Jarosite as an indicator of water-limited chemical weathering on Mars. Nature 431, 821-823.

Fairen A. G., Fernandez-Remolar D., Dohm J. M., Baker V. R. and Amils R. (2004) Inhibition of carbonate synthesis in acidic oceans on early Mars. Nature 431, 423-426.

Fallick A. E., Ilich M. and Russell M. J. (1991) A stable isotope study of the magnesite deposits associated with the Alpine-type ultramafic rocks of Yugoslavia. Econ. Geol. 86, 847-861.

Fernandez-Remolar D. C., Morris R. V., Gruener J. E., Amils R. and Knoll A. H. (2005) The Rio Tinto basin, Spain: mineralogy, sedimentary geobiology, and implications for interpretation of outcrop rocks at Meridiani Planum, Mars. Earth Planet. Sci. Lett. 240, 149-167.

Fishbaugh K. E., Poulet F., Chevrier V., Langevin Y. and Bibring J. P. (2007) On the origin of gypsum in the Mars north polar region. J. Geophys. Res. 112, E07002. http://dx.doi.org/10.1029/ 2006JE002862. 
Franke W. A. and Teschner-Steinhardt R. (1994) An experimental approach to the sequence of the stability of rock-forming minerals towards chemical weathering. Catena 21, 279-290.

Gaillard F. and Scaillet B. (2009) The sulfur content of volcanic gases on Mars. Earth Planet. Sci. Lett. 279, 34-43.

Gendrin A., Mangold N., Bibring J. P., Langevin Y., Gondet B., Poulet F., Bonello G., Quantin C., Mustard J., Arvidson R. and LeMouelic S. (2005) Sulfates in martian layered terrains: the OMEGA/Mars Express view. Science 307, 1587-1591.

Golden D. C., Ming D. W., Morris R. V. and Mertzman S. A. (2005) Laboratory-simulated acid-sulfate weathering of basaltic materials: implications for formation of sulfates at Meridiani Planum and Gusev crater, Mars. J. Geophys. Res. 110, E12S07. http://dx.doi.org/10.1029/2005JE002451.

Golubev S. V., Pokrovsky O. S. and Schott J. (2005) Experimental determination of the effect of dissolved $\mathrm{CO}_{2}$ on the dissolution kinetics of $\mathrm{Mg}$ and $\mathrm{Ca}$ silicates at $25^{\circ} \mathrm{C}$. Chem. Geol. 217, 227238.

Gooding J. L. (1978) Chemical weathering on Mars: thermodynamic stabilities of primary minerals (and their alteration products) from mafic igneous rocks. Icarus 33, 483-513.

Grotzinger J. P., Arvidson R. E., Bell J. F., Calvin W., Clark B. C., Fike D. A., Golombek M., Greeley R., Haldemann A., Herkenhoff K. E., Jolliff B. L., Knoll A. H., Malin M., McLennan S. M., Parker T., Soderblom L., Sohl-Dickstein J. N., Squyres S. W., Tosca N. J. and Watters W. A. (2005) Stratigraphy and sedimentology of a dry to wet eolian depositional system, Burns formation, Meridiani Planum, Mars. Earth Planet. Sci. Lett. 240, 11-72.

Hänchen M., Prigiobbe V., Baciocchi R. and Mazzotti M. (2008) Precipitation in the Mg-carbonate system - effects of temperature and $\mathrm{CO}_{2}$ pressure. Chem. Eng. Sci. 63, 1012-1028.

Halevy I., Zuber M. T. and Schrag D. P. (2007) A sulfur dioxide climate feedback on early Mars. Science 318, 1903-1907.

Herd C. D. K., Borg L. E., Jones J. H. and Papike J. J. (2002) Oxygen fugacity and geochemical variations in the martian basalts: implications for martian basalt petrogenesis and the oxidation state of the upper mantle of Mars. Geochim. Cosmochim. Acta 66, 2025-2036.

Hillier S. (2000) Accurate quantitative analysis of clay and other minerals in sandstones by XRD: comparison of a Rietveld and a reference intensity ratio (RIR) method and the importance of sample preparation. Clays Clay Miner. 35, 291-302.

Hurowitz J. A., Tosca N. J., McLennan S. M. and Schoonen M. A. A. (2007) Production of hydrogen peroxide in Martian and lunar soils. Earth Planet. Sci. Lett. 255, 41-52.

Hurowitz J. A., Fischer W., Tosca N. J. and Milliken R. E. (2010) Origin of acidic surface waters and the evolution of atmospheric chemistry on early Mars. Nat. Geosci. 3, 323-326.

Johnson S. S., Pavlov A. A. and Mischna M. A. (2009) Fate of $\mathrm{SO}_{2}$ in the ancient Martian atmosphere: implications for transient greenhouse warming. J. Geophys. Res. Planets 114, E11011.

King P. L. and McLennan S. M. (2010) Sulfur on Mars. Elements 6, $107-112$.

Klingelhöfer G., Morris R. V., Bernhardt B., Schroder C., Rodionov D. S., de Souza P. A., Yen A., Gellert R., Evlanov E. N., Zubkov B., Foh J., Bonnes U., Kankeleit E., Gutlich P., Ming D. W., Renz F., Wdowiak T., Squyres S. W. and Arvidson R. E. (2004) Jarosite and hematite at Meridiani Planum from Opportunity's Mossbauer spectrometer. Science 306, 1740-1745.

Knauth L. P., Burt D. M. and Wohletz K. H. (2005) Impact origin of sediments at the opportunity landing site on Mars. Nature 438, $1123-1128$.
Lammer H., Lichtenegger H. I. M., Kolb C., Ribas I., Guinan E. F., Abart R. and Bauer S. J. (2003) Loss of water from Mars: implications for the oxidation of the soil. Icarus 165, 9-25.

Langevin Y., Poulet F., Bibring J. P. and Gondet B. (2005) Sulfates in the north polar region of Mars detected by OMEGA/Mars express. Science 307, 1584-1586.

Lesher C. M., Lee R. F., Groves D. I., Bickle M. J. and Donaldson M. J. (1981) Geochemistry of komatiites from Kambalda, Western Australia: I. Chalcophile element depletion, a consequence of sulfide liquid separation from komatiitic magmas. Econ. Geol. 76, 1714-1728.

Liang M.-C., Hartman H., Kopp R. E., Kirschvink J. L. and Yung Y. L. (2006) Production of hydrogen peroxide in the atmosphere of a Snowball Earth and the origin of oxygenic photosynthesis. Proc. Natl. Acad. Sci. USA 103, 18896-18899.

Lorand J. P., Chevrier V. and Sautter V. (2005) Sulfide mineralogy and redox conditions in some shergottites. Meteorit. Planet. Sci. 40, 1257-1272.

Mangold N., Gendrin A., Gondet B., LeMouelic S., Quantin C., Ansan V., Bibring J. P., Langevin Y., Masson P. and Neukum G. (2008) Spectral and geological study of the sulfate-rich region of West Candor Chasma, Mars. Icarus 194, 519-543.

Massé M., Le Mouelic S., Bourgeois O., Combe J. P., Le Deit L., Sotin C., Bibring J. P., Gondet B. and Langevin Y. (2008) Mineralogical composition, structure, morphology, and geological history of Aram Chaos crater fill on Mars derived from OMEGA Mars Express data. J. Geophys. Res. 113, E12006. http://dx.doi.org/10.1029/2008JE003131.

McCollom T. M. and Hynek B. M. (2005) A volcanic environment for bedrock diagenesis at Meridiani Planum on Mars. Nature 438, 1129-1131.

McHenry L. J., Chevrier V. and Schroder C. (2011) Jarosite in a Pleistocene East African saline-alkaline paleolacustrine deposit: implications for Mars aqueous geochemistry. J. Geophys. Res. Planets 116, E04002.

McLennan S. M., Bell Iii J. F., Calvin W. M., Christensen P. R., Clark B. C., de Souza P. A., Farmer J., Farrand W. H., Fike D. A., Gellert R., Ghosh A., Glotch T. D., Grotzinger J. P., Hahn B., Herkenhoff K. E., Hurowitz J. A., Johnson J. R., Johnson S. S., Jolliff B., Klingelhöfer G., Knoll A. H., Learner Z., Malin M. C., McSween, Jr., H. Y., Pocock J., Ruff S. W., Soderblom L. A., Squyres S. W., Tosca N. J., Watters W. A., Wyatt M. B. and Yen A. (2005) Provenance and diagenesis of the evaporitebearing Burns formation, Meridiani Planum, Mars. Earth Planet. Sci. Lett. 240, 95-121.

McSween H. Y. (1994) What we have learned about Mars from SNC meteorites. Meteoritics 29, 757-779.

Mehra O. P. and Jackson M. L. (1960) Iron oxide removal from soils and clays by a dithionite-citrate system buffered with sodium bicarbonate. Clays Clay Miner. 7, 317-327.

Meyer C. (2008) The Mars meteorite compendium. Available from: $<\mathrm{http}: / /$ curator.jsc.nasa.gov/antmet/mmc/ $>$.

Michalski J. R. and Niles P. B. (2010) Deep crustal carbonate rocks exposed by meteor impact on Mars. Nat. Geosci. 3, 751-755.

Moncur M. C., Jambor J. L., Ptacek C. J. and Blowes D. W. (2009) Mine drainage from the weathering of sulfide minerals and magnetite. Appl. Geochem. 24, 2362-2373.

Morris R. V., Klingelhofer G., Schroder C., Rodionov D. S., Yen A., Ming D. W., de Souza P. A., Wdowiak T., Fleischer I., Gellert R., Bernhardt B., Bonnes U., Cohen B. A., Evlanov E. N., Foh J., Gutlich P., Kankeleit E., McCoy T., Mittlefehldt D. W., Renz F., Schmidt M. E., Zubkov B., Squyres S. W. and Arvidson R. E. (2006) Mossbauer mineralogy of rock, soil, and dust at Meridiani Planum, Mars: opportunity's journey across sulfate-rich outcrop, basaltic sand and dust, and hematite lag 
deposits. J. Geophys. Res. 111, E12S15. http://dx.doi.org/ 10.1029/2006JE002791.

Morris R. V., Ruff S. W., Gellert R., Ming D. W., Arvidson R. E., Clark B. C., Golden D. C., Siebach K., Klingelhofer G., Schroder C., Fleischer I., Yen A. S. and Squyres S. W. (2010) Identification of carbonate-rich outcrops on Mars by the spirit rover. Science 329, 421-424.

Murchie S. L., Mustard J. F., Ehlmann B. L., Milliken R. E., Bishop J. L., McKeown N. K., Noe Dobrea E. Z., Seelos F. P., Buczkowski D. L., Wiseman S. M., Arvidson R. E., Wray J. J., Swayze G., Clark R. N., Des Marais D. J., McEwen A. S. and Bibring J.-P. (2009) A synthesis of Martian aqueous mineralogy after 1 Mars year of observations from the Mars Reconnaissance Orbiter. J. Geophys. Res. 114, E00D06.

Naldrett A. J. (2004) Magmatic Sulfide Deposits: Geology, Geochemistry and Exploration. Springer.

Navarro-Gonzalez R., Vargas E., de la Rosa J., Raga A. C. and McKay C. P. (2010) Reanalysis of the Viking results suggests perchlorate and organics at midlatitudes on Mars. J. Geophys. Res. Planets 115, E12010.

Neubeck A., Duc N. T., Bastviken D., Crill P. and Holm N. G. (2011) Formation of $\mathrm{H}_{2}$ and $\mathrm{CH}_{4}$ by weathering of olivine at temperatures between 30 and $70{ }^{\circ} \mathrm{C}$. Geochem. Trans. 12, 6 .

Niles P. B. and Michalski J. (2009) Meridiani Planum sediments on Mars formed through weathering in massive ice deposits. Nat. Geosci. 2, 215-220.

Nordstrom D. K. and Alpers C. N. (1999) Negative pH, efflorescent mineralogy, and consequences for environmental restoration at the Iron Mountain Superfund site, California. Proc. Natl. Acad. Sci. USA 96, 3455-3462.

Ori G. G., Marinangeli L. and Baliva A. (2000) Terraces and Gilbert-type deltas in crater lakes in Ismenius Lacus and Memnonia (Mars). J. Geophys. Res. Planets 105, 17629-17641.

Papike J. J., Karner J. M., Shearer C. K. and Burger P. V. (2009) Silicate mineralogy of martian meteorites. Geochim. Cosmochim. Acta 73, 7443-7485.

Peslier A. H., Hnatyshin D., Herd C. D. K., Walton E. L., Brandon A. D., Lapen T. J. and Shafer J. T. (2010) Crystallization, melt inclusion, and redox history of a Martian meteorite: olivine-phyric shergottite Larkman Nunatak 06319. Geochim. Cosmochim. Acta 74, 4543-4576.

Phillips R. J., Zuber M. T., Solomon S. C., Golombek M. P., Jakosky B. M., Banerdt W. B., Smith D. E., Williams R. M. E., Hynek B. M., Aharonson O. and Hauck S. A. (2001) Ancient geodynamics and global-scale hydrology on Mars. Science 291, 2587-2591.

Pollack J. B., Kasting J. F., Richardson S. M. and Poliakoff K. (1987) The case for a wet, warm climate on Early Mars. Icarus 71, 203-224.

Righter K., Pando K. and Danielson L. R. (2009) Experimental evidence for sulfur-rich martian magmas: implications for volcanism and surficial sulfur sources. Earth Planet. Sci. Lett. 288, 235-243.

Roach L. H., Mustard J. F., Swayze G., Milliken R. E., Bishop J. L., Murchie S. L. and Lichtenberg K. (2010) Hydrated mineral stratigraphy of Ius Chasma, Valles Marineris. Icarus 206, 253268.

Robigou V., Delaney J. R. and Stakes D. S. (1993) Large massive sulfide deposits in a newly discovered active hydrothermal system, The High-Rise Field, Endeavour Segment, Juan De Fuca Ridge. Geophys. Res. Lett. 20, 1887-1890.

Rochette P., Lorand J.-P., Fillion G. and Sautter V. (2001) Pyrrhotite and the remanent magnetization of SNC meteorites: a changing perspective on Martian magnetism. Earth Planet. Sci. Lett. 190, 1-12.

Rochette P., Fillion G., Ballou R., Brunet F., Ouladdiaf B. and Hood L. (2003) High pressure magnetic transition in pyrrhotite and impact demagnetization on Mars. Geophys. Res. Lett. 30(13), 1683. http://dx.doi.org/10.1029/2003GL017359.

Schröder C., Klingelhöfer G. and Tremel M. (2004) Weathering of Fe-bearing minerals under Martian conditions, investigated by Mossbauer spectroscopy. Planet. Space Sci. 52, 997-1010.

Sherlock E. J., Lawrence R. W. and Poulin R. (1995) On the neutralization of acid rock drainage by carbonate and silicate minerals. Environ. Geol. 25, 43-54.

Squyres S. W., Grotzinger J. P., Arvidson R. E., Bell J. F., Calvin W., Christensen P. R., Clark B. C., Crisp J. A., Farrand W. H., Herkenhoff K. E., Johnson J. R., Klingelhofer G., Knoll A. H., McLennan S. M., McSween H. Y., Morris R. V., Rice J. W., Rieder R. and Soderblom L. A. (2004) In situ evidence for an ancient aqueous environment at Meridiani Planum, Mars. Science 306, 1709-1714.

Szynkiewicz A., Modelska M., Buczynski S., Borrok D. and Pratt L. (2010) Sulfide weathering in the Werenskioldbreen, Spitsbergen - a polar terrestrial analogue for gypsum deposition in the North Polar Region of Mars. AGU Fall Meeting, \#P13B1382 (abstr.).

Tosca N. J., McLennan S. M., Lindsley D. H. and Schoonen M. A. A. (2004) Acid-sulfate weathering of synthetic Martian basalt: the acid fog model revisited. J. Geophys. Res. Planets 109, E05003. http://dx.doi.org/10.1029/2003JE002218.

Vickery A. M. and Melosh H. J. (1987) The large crater origin of SNC meteorites. Science 237, 738-743.

Weiss B. P., Vali H., Baudenbacher F. J., Kirschvink J. L., Stewart S. T. and Shuster D. L. (2002) Records of an ancient Martian magnetic field in ALH84001. Earth Planet. Sci. Lett. 201, 449463.

Wendt L., Gross C., Kneissl T., Sowe M., Combe J. P., Le Deit L., McGuire P. C. and Neukum, G. (2010) Sulfates and iron oxides in Ophir Chasma, Mars. Lunar Planet. Sci. Conf. XLI, \#1699 (abstr.).

Wray J. J., Murchie S. L., Ehlmann B. L., Milliken R. E., Seelos K. D., Noe Dobrea E. Z., Mustard J. F. and Squyres S. W. (2011) Evidence for regional deeply buried carbonate-bearing rocks on Mars. Lunar Planet. Sci. Conf. XLII, \#2635 (abstr.).

Yen A. S., Kim S. S., Hecht M. H., Frant M. S. and Murray B. (2000) Evidence that the reactivity of the martian soil is due to superoxide ions. Science 289, 1909-1912.

Zent A. P. (1998) On the thickness of the oxidized layer of the Martian regolith. J. Geophys. Res. Planets 103, 31491-31498.

Zolotov M. Y. and Shock E. L. (2005) Formation of jarositebearing deposits through aqueous oxidation of pyrite at Meridiani Planum, Mars. Geophys. Res. Lett. 32, L21203. http://dx.doi.org/10.1029/2005GL024253.

Associate editor: Roy A. Wogelius 